\title{
CAREER BREAKS AFTER CHILDBIRTH: THE IMPACT OF FAMILY LEAVE REFORMS IN THE CZECH REPUBLIC
}

\author{
Alena Bičáková \\ Klára Kalíšková
}

Charles University

Centerfor Economic Research and Graduate Education Academy of Sciences of the Czech Republic

Economic Institute

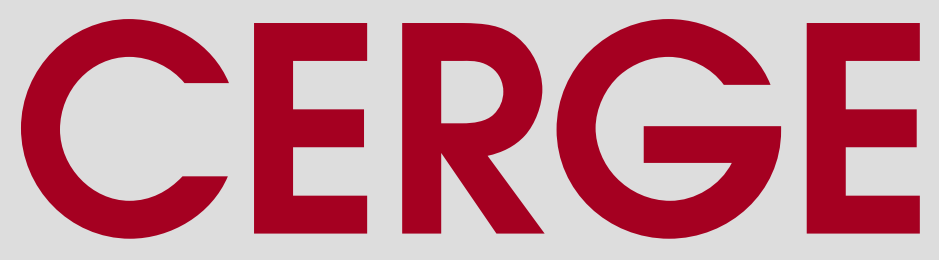




\title{
Working Paper Series $\quad 568$ (ISSN 1211-3298)
}

\section{Career Breaks after Childbirth: The Impact of Family Leave Reforms in the Czech Republic}

\author{
Alena Bičáková \\ Klára Kalíšková
}

CERGE-EI

Prague, December 2016 
ISBN 978-80-7343-375-8 (Univerzita Karlova v Praze, Centrum pro ekonomický výzkum a doktorské studium)

ISBN 978-80-7344-391-7 (Národohospodářský ústav AV ČR, v. v. i.) 


\title{
Career Breaks after Childbirth: The Impact of Family Leave Reforms in the Czech Republic*
}

\author{
Alena Bičáková ${ }^{\dagger}$ \\ CERGE-EI ${ }^{\ddagger}$
}

\author{
Klára Kalíšková $\$$ \\ CERGE-EI, University of Economics Prague, and IZA
}

December $2016 \mathbb{1}$

\begin{abstract}
The Czech Republic is a country with a strong attachment of women to the labor market, but with one of the longest paid family leaves, which is often followed by a spell of unemployment. Using a difference-in-differences methodology, we study the impact of two reforms of the duration of the parental allowance on the labor market status of mothers 2-7 years after childbirth. While the 1995 reform prolonged the allowance from 3 to 4 years, the 2008 reform allowed some parents to shorten the duration of the allowance to only 2 or 3 years with an equivalent total monetary amount. We find that in response to the 1995 reform, $36 \%$ of mothers extended their family leave beyond the 3 -year job protection period. The 2008 reform partially reversed this effect. Both reforms also had a considerable impact on post-leave unemployment and inactivity of mothers.
\end{abstract}

JEL codes: J13, J18, J22

Keywords: family leave, female labor supply, unemployment, policy evaluation

*This paper was financially supported by the Czech Science Foundation, grant number 1436154G. This paper is based on data from the Czech Statistical Office, Labour Force Survey 1993-2013. The responsibility for all remaining errors and conclusions drawn from the data lies entirely with the authors.

${ }^{\dagger}$ Email:alena.bicakova@cerge-ei.cz.

${ }^{\ddagger}$ CERGE-EI, a joint workplace of Charles University in Prague and the Economics Institute of the Czech Academy of Sciences, Politických vězñu 7, Prague 1, 111 21, Czech Republic. Address: CERGE-EI, P.O.Box 882, Politických vězňů 7, 11121 Prague 1, Czech Republic.

§Email:klara.kaliskova@cerge-ei.cz.

IThis is a revised version of a working paper originally published under the same title and number in August 2016. 


\section{Introduction}

Work experience and job tenure are crucial for career development and wage growth. Although fathers increasingly participate in caring for their children, career breaks after childbirth remain an important cause of gender differences in labor market outcomes. $^{1}$

These career breaks are to a great extent determined by family leave policies, which typically regulate the length of the job protection (which enables mothers to return to their pre-birth jobs) and the amount and the duration of the allowance (which provides mothers with financial support). The impact of family leave policies on mothers' outcomes varies with leave's duration. Family leave of several months promotes female labor force participation, employment and future earnings (Hashimoto et al. 2004, Baker and Milligan 2008, Han, Ruhm, and Waldfogel 2009). Family leave of several years has adverse effects on mothers' labor market outcomes, at least in the short run (Schone 2004, Lalive and Zweimüller 2009, Schönberg and Ludsteck 2014). ${ }^{2}$

While the majority of the existing empirical evidence presents the effect of the reforms of family leave shorter than three years, ${ }^{3}$ much less is known about the impact of paid family leave with longer duration, implemented, for example, in some

\footnotetext{
${ }^{1}$ Negative effects of career breaks on women's wages are documented e.g. by Anderson, Binder, and Krause (2002), Spivey (2005), Miller (2011), Ejrnaes and Kunze (2013). Impact on skill depreciation and occupational choice is studied e.g. in Francesconi (2002), Adda, Dustmann, and Stevens (2011). The importance of work interruptions for gender wage gaps is discussed in Blau and Kahn (2006) and Blau and Kahn (2016). A positive cross-country correlation of the duration of paid family leave with gender wage gaps and with gender unemployment gaps is documented in OECD (2012) and Bičáková (2012), respectively.

${ }^{2}$ Interestingly, positive impact on (long-term) child outcomes was also found for shorter family leaves (Carneiro, Loken, and Salvanes 2015) rather than for leaves of longer duration (Baker and Milligan 2010, Dustmann and Schönberg 2012).

${ }^{3}$ The mostly studied reform in the U.S. is the 1993 introduction of 12-week unpaid leave (Baum 2003, Berger and Waldfogel 2004, Hashimoto et al. 2004, Han, Ruhm, and Waldfogel 2009). While the reforms in Canada (Baker and Milligan 2008) and selected EU countries (Lalive and Zweimüller 2009 and Lalive et al. 2014 for Austria; Ejrnaes and Kunze 2013, Fitzenberger, Sommerfeld, and Steffes 2013, Schönberg and Ludsteck 2014, Bergemann and Riphahn 2015, or Geyer, Haan, and Wrohlich 2015 for Germany or Dahl et al. 2016 for Norway) involve longer family leaves, the duration of the paid family leave never extends beyond two years.
} 
of the post-Communist countries of Central and Eastern Europe (Moos 2015). This paper provides estimates of the effect of a very long (up to 4 years) paid family leave on labor market status of mothers with young children, using two reforms of parental leave allowance implemented in the Czech Republic in 1995 and 2008. ${ }^{4}$ While the 1995 reform increased the duration from 3 to 4 years, the 2008 reform allowed women to receive the same total amount of allowance over 3 years (conditional on working before birth) or even over 2 years (conditional on having sufficiently high pre-birth wage). ${ }^{5}$ As the duration of the job protection remained unchanged at 3 years after childbirth during the studied period, our estimates reflect solely the impact of the monetary aspect of a family leave.

The Czech Republic provides a unique economic setting for the estimation of the impact of a very long family leave on labor market outcomes of mothers with young children. A strong overall attachment of Czech women to the labor force (a heritage of the Communist regime, see e.g. Fodor 2005) contrasts sharply with the absence of mothers of children younger than 3 from the labor market. ${ }^{6}$ A combination of one of the longest paid family leaves with one of the highest take up rates in the EU (OECD 2010) and very limited early institutional childcare ${ }^{7}$ places the Czech Republic among the three EU countries (together with Slovakia and Hungary) with the most sizable consequences of childbirth on mothers' employment (defined as a percentage point difference between the employment rate of childless women and women with at least one child under 6). Figure 1 shows the Czech Republic in the international context and further illustrates the strong positive relationship between

\footnotetext{
${ }^{4}$ Parental leave constitutes the second part of the family leave, following a shorter but more highly paid maternity leave. We provide the details of the family leave policies in Section 2.1.

${ }^{5}$ The 2-year option was, however, chosen by very few women and the take-up rate was still only $6 \%$ in 2011 (according to the Czech Ministry of Labour and Social Affairs statistics).

${ }^{6}$ When we exclude mothers with children 0-3, the labor force participation of the prime-age women is as high as $93 \%$. The situation is similar in other Central and Eastern European countries, but the employment rate of women without children younger than 3 is the highest in the Czech Republic (Fodor 2005).

${ }^{7}$ Only $0.4 \%$ of children younger than 3 were enrolled in institutional childcare in 2012 (source: Institute for Health Information and Statistics of the Czech Republic).
} 
the duration of paid family leave and the impact of motherhood on employment across EU countries.

Figure 1: Family leave and employment impact of motherhood in the EU countries.

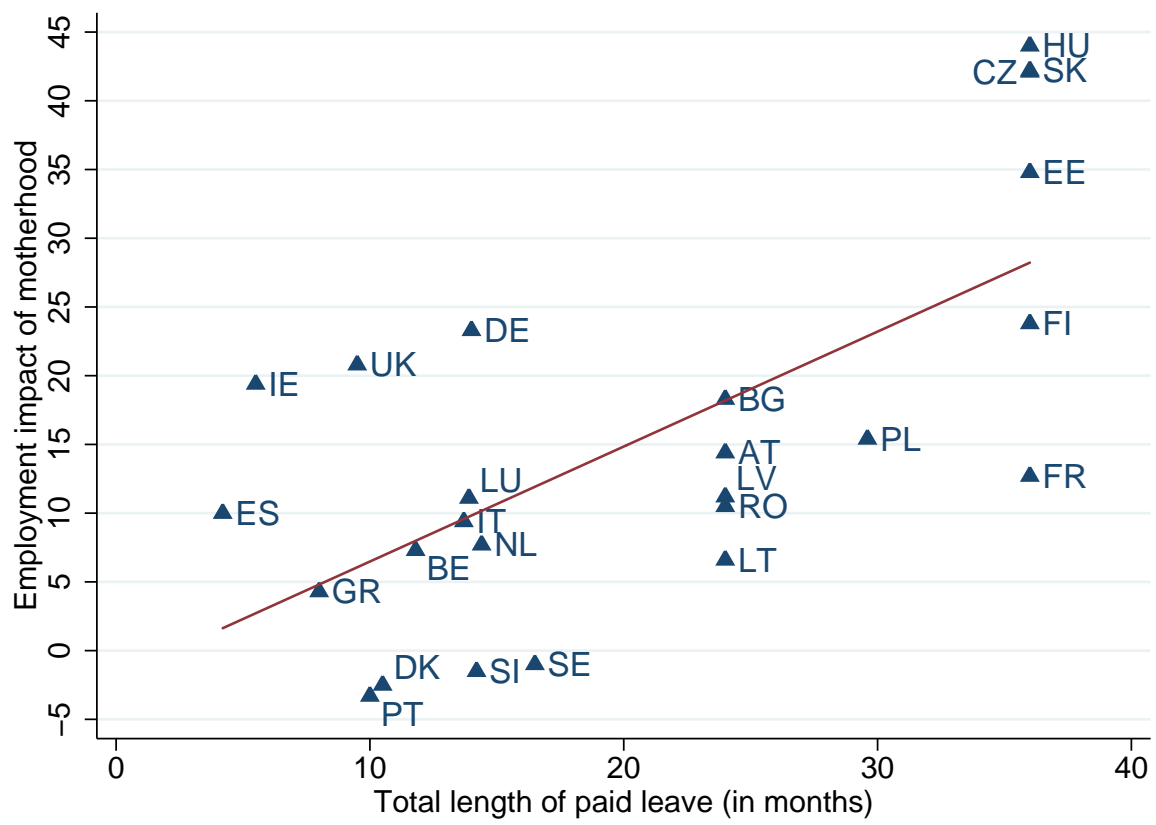

Note: The total length of paid leave is the statutory maximum length of postnatal paid leave (in months) in 2012. The employment impact of motherhood is the difference between the employment rate of childless women and women with at least one child under 6 (in percentage points) in 2013. Source: Annual reviews of the International Network on Leave Policies and Research and EUROMOD country reports for the length of leave. Eurostat: Employment rate of adults by gender, age groups, highest level of education attained, number of children and age of youngest child for the employment impact of motherhood.

Is the employment impact of motherhood just driven by the length of the paid family leave? Or do long family leaves affect mothers labor market status even beyond the statutory duration? ${ }^{8}$ Our data reveal that paid family leave in the Czech Republic is often followed by a spell of unemployment. Over $50 \%$ of women who terminate their family leave when their children are 2-5, return to the labor force as unemployed and over $80 \%$ of those unemployed with children under 5 enter

${ }^{8} \mathrm{~A}$ chance of mother's return to a pre-birth job is likely to decline with the time spent at home, especially when job protection is weak or expires. Alternatively, a longer family leave may affect mothers preferences and make them wish to spend even more time with the child (Schönberg and Ludsteck 2014). 
unemployment immediately after the end of the family leave. ${ }^{9}$ Interestingly, very few of these women withdraw from the labor force in the long run. ${ }^{10}$ An important consequence of a very long family leave on women's labor market outcomes, often neglected by the policy makers, is thus the break in the career due to the loss of pre-birth job and the subsequent period of unemployment. The evaluation of the impact of short or medium-length family leaves on mothers labor market status, however, focuses almost solely on employment. ${ }^{11}$ The only exception is Lalive et al. (2014) who also study the impact on post leave unemployment. ${ }^{12}$

Following the existing research, we first estimate the impact of the two reforms of paid family leave in the Czech Republic on mothers' non-employment. ${ }^{13}$ In order to separate the impact of the reforms on the initial paid family leave (the intended effects of the reforms on mothers absence from the labor market under the family leave provisions) from the impact on post-leave unemployment spell and labor force withdrawal (the effects unintended by the reforms), we then distinguish between mothers unemployment and inactivity as two different labor market outcomes. ${ }^{14}$

In particular, we focus on the labor market status of women 2-7 years after childbirth. ${ }^{15}$ We estimate the impact of the reforms separately by the age of

\footnotetext{
${ }^{9}$ These numbers are based on labor market transitions observed for a subset of women in the Czech Labor Force Survey in 2011-2014.

${ }^{10}$ In $2014,87 \%$ of Czech mothers became employed again by the time their child is 7 .

${ }^{11}$ See, for example, Baum (2003), Baker and Milligan (2008), Lalive and Zweimüller (2009), Fitzenberger, Sommerfeld, and Steffes (2013), Schönberg and Ludsteck (2014) or Geyer, Haan, and Wrohlich (2015).

${ }^{12}$ Das and Polachek (2015) also consider the impact of family leave regulations on unemployment, but they study the impact on unemployment of all young women, not specifically that of mothers after childbirth.

${ }^{13}$ The non-employment rate is the share of population that is not in employment. It is equal to 1 minus the employment rate (used in the previous studies).

${ }^{14}$ The terminology of the intended and unintended effects of the reforms is adopted from Lalive and Zweimüller (2009). Inactive individuals are those not in the labor force, i.e. neither employed, nor unemployed. We discuss the distinction between the unemployed and the inactive (i.e. those not in the labor force) in Sections 2.2 and 3.2.

${ }^{15} \mathrm{We}$ omit the first 2 years, as almost all women with children younger than 2 are on family leave in our sample. Moreover, the first two years were covered by the family leave throughout the entire period of our analysis and therefore unaffected by the reforms. By the age of 7 , all children are at elementary school and a majority $(87 \%$ in 2014) of their mothers are again employed.
} 
their youngest child using a differences-in-differences design. We follow the standard approach in the literature (see for example, Naz 2004, Schone 2004, SánchezMangas and Sánchez-Marcos 2008, Geyer, Haan, and Wrohlich 2015, Bergemann and Riphahn 2015) and choose women with older children to control for the aggregate trends in the labor market. ${ }^{16}$ The 1995 Czech reform is also studied by Mullerova (2014) who estimates the impact on employment of mothers of 3 year old children using an alternative difference-in-differences approach. ${ }^{17}$ Mullerova (2016) then evaluates the impact of the 2008 reform on the first affected cohort of mothers with a difference-in-differences approach using previous cohorts of mothers and mothers with older children as control groups. Comparison of the results from the two studies of Mullerova with the overlapping subset of our estimates suggests that our findings are robust to different identification strategies.

Our study is closely related to that of Lalive et al. (2014) and Schönberg and Ludsteck (2014): We estimate an impact of multiple reforms in a single country with maximum paid family leave of several years (24 months in Germany, 30 months in Austria, and as much as 48 months in the Czech Republic). Each study involves a reform that prolonged the allowance receipt beyond the job protection period, as well as a reform which extended the job protection period beyond the allowance duration. Lalive et al. (2014) and Schönberg and Ludsteck (2014) find that extending the (in particular, job protected) paid family leave partly delays women's return-to-work after childbirth in the short-run but that it does neither hurt, nor help the long-

\footnotetext{
${ }^{16}$ An alternative method used in Schönberg and Ludsteck (2014) or Lalive et al. (2014) combines the regression discontinuity design around the childbirth with the difference-in-difference estimation controlling for the age and seasonal effects. The design of the Czech reforms (the reforms affected also parents already on family leave) and the data limitations (the LFS data do not have information about the date of birth) preclude us from using similar approach.

${ }^{17}$ In particular, the author compares mothers whose child reached 3 in the year before the reform to mothers whose child reached 3 in the year after the reform. To control for seasonal effects, she uses an evolution of the same groups of women in years 1997-1998, when no reform occurred. We find the assumption of similar time trends across the two periods too strong, given the macroeconomic development after 1997, when financial and economic crises hit the Czech economy.
} 
run outcomes, including the probability of job continuity. In contrast with their findings, we show that the impact of the two reforms in the Czech Republic on the labor market outcomes of mothers after childbirth was substantial both in the short (under the paid family leave entitlements) and long run. In response to the 1995 reform, which extended the allowance receipt from 3 to 4 years, around $40 \%$ of mothers prolonged their family leave beyond their child's third birthday (the end of the job protection period). ${ }^{18}$ The 2008 Czech reform, which allowed some mothers to spread the total allowance receipt to only 2 or 3 years, shortened the family leave of at least one fourth of mothers. ${ }^{19}$

Overall, the 1995 reform increased the non-employment rate among mothers with children younger than 8 from $47 \%$ to $53 \%$, while the 2008 reform reduced it from $56 \%$ to $53 \%$. The unintended effects of the two reforms on the post-leave labor force status of women can be summarized as follows: The 1995 reform increased the non-employment rate among mothers of children aged 4-7 (i.e. beyond the new statutory duration) from $16 \%$ to $21 \%$, out of which the occurrence of post-leave unemployment went up from $7 \%$ to $10 \%$ and that of post-leave inactivity from $9 \%$ to $11 \%$. The 2008 reform, on the other hand, has reduced the non-employment rate among mothers with children 4-7 (i.e. beyond the maximum new statutory duration) from $27 \%$ to $23 \%$, with a decrease in the occurrence of unemployment from $15 \%$ to $13 \%$ and in post-leave inactivity from $12 \%$ to $10 \%$.

Why the (unintended) effects of the two reforms in the Czech Republic are greater than those in Lalive et al. (2014) and Schönberg and Ludsteck (2014)? A very long

\footnotetext{
${ }^{18}$ This is in stark contrast with the impact of the 1986 reform in Baden-Württemberg in Germany, which extended the allowance receipt to 22 months but the job protection period to only 10 months, that reduced the employment rate between 10 and 22 months by less than 10 p.p. (Schönberg and Ludsteck 2014). It is also a more sizable effect than in Lalive et al. (2014), who find that the 2000 reform in Austria, which extended allowance duration from 18 to 30 months keeping job protection at 24 months, increased the time mothers spent at home by 3 months.

${ }^{19}$ As the choice of these faster tracks of the allowance receipt was optional and offered only to a subset of eligible women, the results of the impact of the 2008 Czech Reform are not directly comparable to any of the reforms evaluated in Lalive et al. (2014) or Schönberg and Ludsteck (2014).
} 
paid family leave, insufficient institutional childcare, absence of flexible forms of work and probably weaker enforcement of the job protection are some of the candidate explanations, which need to be considered by future research. The size of the impact of the reforms is also likely to be affected by the high compliance of Czech women with the family leave policy, possibly driven by strong pro-family social norms, ${ }^{20}$ as well as by the traditionally high overall participation rate of women in a postCommunist labor market. ${ }^{21}$

The paper is organized as follows: The next section is devoted to the institutional background of the two reforms. We then present our empirical strategy and descriptive evidence of changes in labor market status of women after childbirth. The results section is followed by a robustness analysis and conclusions.

\section{Institutional Background}

\subsection{Family Leave Policies}

Family leave policies in the Czech Republic include job protection, maternity benefits, and parental allowance. Czech parents are eligible for job-protected leave until the child's third birthday. ${ }^{22}$ The 3 -year long job protection period was introduced in 1990 and has not changed since. The strength of job protection in transition economies, however, has been often questioned in the literature (Kantorova 2004,

\footnotetext{
${ }^{20}$ There are about $95 \%$ of women with a child younger than 1 on leave in our data, whereas Schönberg and Ludsteck (2014) estimate the leave take-up rate among West German women who gave birth in early 1990 s to be at most $55 \%$.

${ }^{21}$ Namely, as family leave reforms affect, in particular, women attached to the labor market, they are likely to have a greater impact in countries with (and at times of) higher overall female labor force participation. Note that Schönberg and Ludsteck (2014) estimate only the impact on women from West Germany.

${ }^{22}$ All employees employed on a permanent contract are eligible for job protection. An employee with a fixed-term contract is also eligible for job protection, but only up to the date of contract expiration.
} 
Fodor 2005). ${ }^{23}$

Czech women who were employed for at least 270 days in the 2 years prior to a child's birth are entitled to receive maternity benefits for 28 weeks (starting 6 to 8 weeks prior to birth). Maternity benefits pay $70 \%$ of a woman's salary from the last 12 months prior to the commencement of maternity leave. There were no substantial changes to maternity benefits since $1990 .^{24}$

A parent caring for a child is also eligible for parental allowance, a non-meanstested flat rate benefit. The parental allowance starts either immediately after maternity benefits end or right after childbirth if the mother is not eligible for maternity benefits. $^{25}$ The eligibility criteria for the parental allowance required the parent to earn below a certain threshold (in force until 2004, when the threshold was CZK 3480 per month-one fifth of the average wage at that time) and the child could not attend a childcare facility for more than a certain amount of time per month (this clause remains in force today). Given very few part-time jobs in the Czech Republic, the income threshold strongly discouraged women from labor force participation while receiving parental allowance until $2004 .{ }^{26}$ The limit on the use of the institutional childcare, however, was binding only in the fourth year since childbirth during the studied period, as facilities for children under 3 were almost non-existent

\footnotetext{
${ }^{23}$ There is some anecdotal evidence that Czech employers often try to evade the job protection rule and/or discourage women from returning to their previous jobs even in times of economic prosperity (Kucharova 2006). Moreover, Czech women often tend to associate their family leave with the duration of the allowance rather than with the job protection period (Krizkova et al. 2011).

${ }^{24}$ From 1990 to 2007 , maternity benefits paid $69 \%$ of a woman's salary and were increased by 1 percentage point to $70 \%$ in 2008 . The amount of maternity benefits is reduced for higher income levels using reduction bands and has a maximum threshold. There was no substantial change in the reduction bands with the exception of 2009, when the maximum amount of maternity benefits was doubled. However, this change only affected women who earned more than three times the average female wage at that time.

${ }^{25}$ There is no paternity leave. Parental allowance can, in principle, be received by a father but this is very rare (1.8\% of parental allowance recipients were fathers in 2015), as men's jobs still represent the main source of income for a majority of families.

${ }^{26}$ As 2004 is the first year of the second period (used for the estimation of the 2008 reform), this change does not alter our results. Moreover, there are no discernible breaks around 2004 in the data that would suggest the pre-2004 income threshold had substantial impact on mothers post-birth labor force participation behavior (see Section 4).
} 
due to the massive closure of public nurseries in early 1990s. The absence of early institutional childcare is one of the key reasons only very few mothers work while receiving parental allowance even today. ${ }^{27}$

\section{The 1995 Reform}

Until 1995, duration of parental allowance coincided with the three-year job-protected leave. In October 1995, parental allowance duration was prolonged until the child's fourth birthday and thus exceeded the unchanged job protection leave by one year. All parents with children under 4 as of October 1, 1995 (i.e. not only the parents of the newborns) were eligible for the prolonged parental allowance.

The monthly allowance payment increased only slightly from CZK 1,740 to CZK 1,848 (about 50 euros, which corresponded to one fourth of an average wage in the economy) in 1995. This minor change was part of the gradual increase in the monthly allowance over the 1990s and early 2000s (Figure 2). When evaluating the impact of the 1995 reform, we focus on 1993-1999, during which the monthly allowance payment experienced only negligible changes relative to the extension of the duration of the allowance by 1 year, and the corresponding rise in the total amount of benefits received. A substantial increase in the amount of the parental allowance took place only in 2007, when the monthly amount doubled (from CZK 3,696 to CZK 7,580, which corresponded to an increase from EUR 104 to 213 in year 2000 euros, see Figure 2). However, this change was in force for one year only. In 2008, there was a major reform of the parental allowance and all parents (also those with children born before 2008) had to switch to the new system

\footnotetext{
${ }^{27}$ Only $0.4 \%$ of children younger than 3 were enrolled in institutional childcare and fewer than $6 \%$ of women worked while receiving the parental allowance in 2012 (source: Institute for Health Information and Statistics of the Czech Republic; Survey of Income and Living Conditions 2012, author's calculations).
} 
Figure 2: Monthly parental allowance in the Czech Republic, 1990-2014.

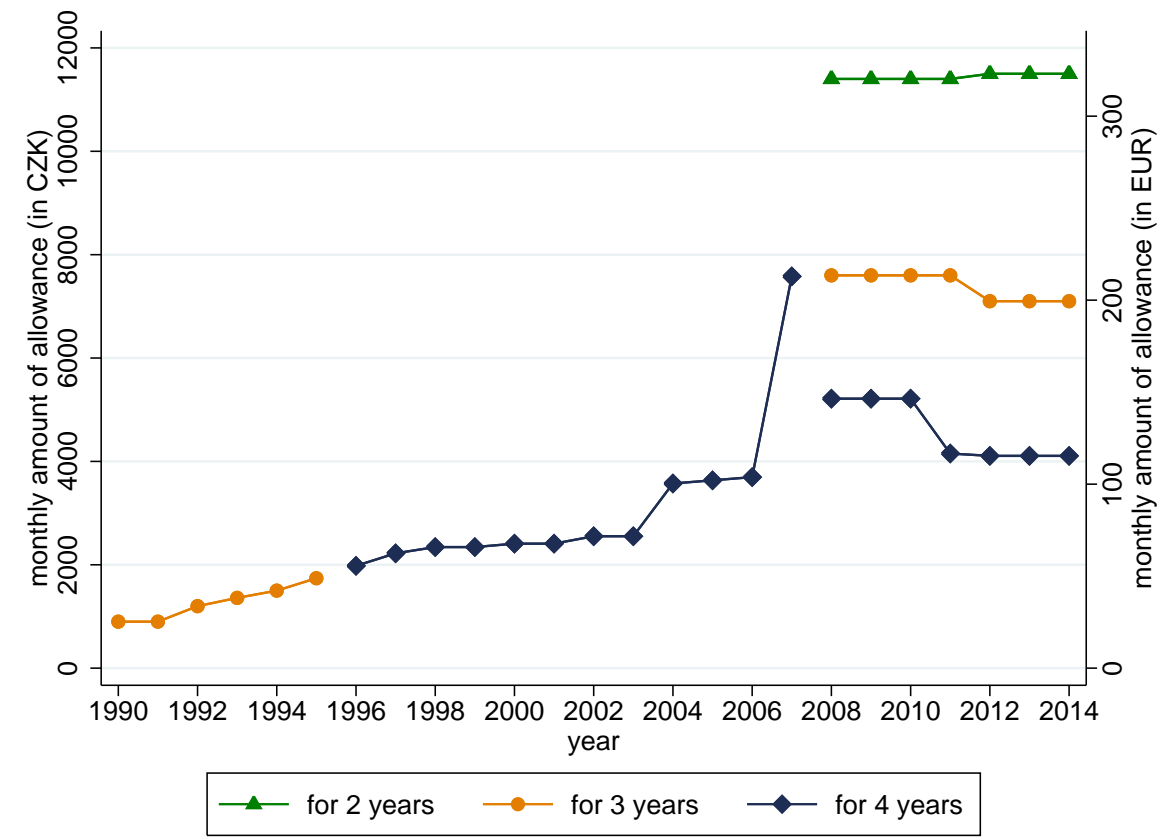

Note: The figure depicts the average monthly amount of parental allowance for each maximum length of the allowance. The right axis reports amounts expressed in year 2000 euros.

\section{The 2008 Reform}

Since January 1, 2008, parents have been allowed to choose the length and the corresponding level of the monthly parental allowance. The shortest track paid CZK 11,400 (EUR 320, in year 2000 euros) per month until the child's second birthday, the standard track paid CZK 7,600 (EUR 213) until the child's third birthday, and the longest track paid CZK 7,600 until the child was 21 months old and then CZK 3,800 (EUR 107) until the child's fourth birthday (see Figure 2). All parents were entitled to the 4-year track. Entitlement to the 3-year track was conditional on one of the parents having worked for at least 270 days in the 2 years prior to birth. If, in addition, one parent earned on average at least CZK 16,500 (EUR 463) per month in the 12 months prior to the birth, ${ }^{28}$ they were also eligible for the 2-year track.

The new system of parental allowance covered not only parents of children born

\footnotetext{
${ }^{28}$ In 2008, an average male wage was CZK 29,429 and an average female wage CZK 21,789.
} 
after January 2008. All parents of children younger than 22 weeks as of January 2008 could choose the 2-year, 3-year or 4-year track, and parents with children younger than 21 months as of January 2008 were eligible for the 3- or 4-year track, conditional on fulfilling the other eligibility criteria. ${ }^{29}$

There were some minor changes to the parental allowance scheme after 2008. The monthly amounts of the allowance decreased for the 4-year track in 2011 (it only paid CZK 7,600 until the child was 9 months old and then CZK 3,800 until the child's fourth birthday) and for the 3-year track in 2012 (from CZK 7,600 to CZK 7,100 per month). The purpose of these changes was to unify the total amount of allowance per child for all tracks. Since 2012, the maximum total amount of allowance per child has been CZK 220,000 (EUR 6,180), regardless of the length of parental allowance.

When we evaluate the impact of the 2008 reform, we focus on 2004-2013. We abstract from the other changes, as they are minor relative to the introduction of the flexible parental allowance system and they do not alter the duration of paid parental leave. We exclude the cohorts affected by the 2007 and 2011 changes from the estimation of the impact of the 2008 reform as part of the robustness checks in Section 5.3.

\subsection{Unemployment Benefits}

Given the high occurrence of unemployment among mothers after the paid family leave, we also need to consider the monetary incentives provided by the unemployment benefit scheme. In general, unemployed individuals in the Czech Republic are eligible for earnings-related unemployment benefits during their first 6 months of unemployment if they worked for at least 12 months in the prior 3 years. An

\footnotetext{
${ }^{29}$ Therefore, the statutory paid family leaves of first women who took advantage of the shorter tracks ended in 2009 the earliest.
} 
individual who cared for a child under 3 for at least 12 months in the last 3 years is also eligible for unemployment benefits. However, when eligibility for unemployment benefits is based on the time spent caring for a child instead of formal work, the amount of unemployment benefits is much lower, corresponding to about $55 \%$ of the parental allowance after 1995 and about 34\% of the allowance for the 3-year track after 2008.Mothers who become unemployed after the paid family leave therefore experience a substantial drop in their monthly funds. ${ }^{30}$ Mothers who become inactive or are unemployed for more than 6 months receive no benefits but have their health insurance covered by the state until their child turns 7 .

\section{Empirical Strategy}

\subsection{Difference-in-Differences Approach}

We estimate the impact of the 1995 and 2008 reforms on mothers' labor market status separately by the age of their youngest child. Women whose youngest child is $2,3,4,5,6$ or 7 at the time of the survey therefore constitute separate treatment groups. ${ }^{31}$ We follow the standard approach in the literature (Naz 2004, Schone 2004, Sánchez-Mangas and Sánchez-Marcos 2008, Geyer, Haan, and Wrohlich 2015, Bergemann and Riphahn 2015) and use mothers with older children to control for the aggregate trends and business cycle effects on the labor market. The control group is the same for all the treatment groups and consists of women whose youngest child is $8-13$ at the time of the survey. ${ }^{32}$ Our empirical strategy assumes that

\footnotetext{
${ }^{30}$ The only exception are women on the 4-year track of the parental allowance, whose monthly allowance of 3,800 CZK (after the first 9 months, since 2008) is comparable to the unemployment benefit they receive for the first 6 months of unemployment if they become unemployed when their parental allowance expires.

${ }^{31}$ Since eligibility for the parental allowance is universal for parents of children under a given age threshold, the treatment group consists of all women with children of a given age.

${ }^{32}$ While these women were likely to face similar labor market conditions as mothers with somewhat younger children, they were not affected by the reform, because they were only entitled to parental leave in the pre-reform system with their youngest child.
} 
trends in labor market status of the treatment groups and that of the control group would have been the same in the absence of treatment, and that there were no significant composition changes in the two groups. We discuss the validity of these two assumptions in Appendix B.

The estimation period covers 7 years of data around the 1995 reform (1993$1999)^{33}$ and 10 years of data around the 2008 reform (2004-2013). These time spans are chosen so that women whose youngest child is 8-13 during the estimation period (our control group) have not been affected by either of the two reforms.

For each group of treated women (defined by the age of their youngest child) and for each reform, we estimate the following equation:

$$
Y_{i t}=\beta_{0}+\beta_{1} \text { Treat }_{i}+\beta_{2} \text { After }_{t}+\beta_{3}\left(\text { Treat }_{i} * \text { After }_{t}\right)+X_{i t}^{\prime} \theta+\gamma_{t}+\gamma_{g t}+\epsilon_{i t} .
$$

The outcome of interest $\left(Y_{i t}\right)$ is a binary variable that denotes a woman's labor market status. We first estimate the impact of the reforms on non-employment, which includes both unemployment and inactivity, and then focus on unemployment and inactivity separately. Treat ${ }_{i}$ is the fixed effect for the treatment group and $A$ fter $_{t}$ is the fixed effect for the after-reform period. The impact of the parental allowance reforms is captured by $\beta_{3}$, the coefficient of the indicator variable for the treated women in the after-reform period. The before period covers data from the first quarter of 1993 to the third quarter of 1995 for the 1995 reform, and data from 2004 to 2007 for the 2008 reform. The beginning of the after period differs across the treatment groups. It is given by the year when the children of the first cohort of mothers affected by the reforms (children born in 1992 for the 1995 reform and in 2006 for the 2008 reform) reach the age by which the treatment group is defined. ${ }^{34}$

\footnotetext{
${ }^{33}$ The collection of the Czech LFS data started only in 1993.

${ }^{34}$ For example, the after period for mothers with 5 year old children starts in the year when the children of the first affected cohort become 5. See Appendix Table A.1 for more detail.
} 
The after-period for the control group is set to match the after-period for the given treatment group. We also control for the common time trend in the labor supply using fixed effects for each quarter-year combination $\left(\gamma_{t}\right)$, for education-specific time trends using interactions between the quarter-year fixed effects and four educational groups $\left(\gamma_{g t}\right)$, and for the observable characteristics $\left(X_{i t}\right)$ including quadratic polynomial of age, four education dummies, dummy variables for cohabiting and married women, number of children, dummy variable for presence of elderly household members, and regional fixed effects.

\subsection{Data Description and Key Definitions}

We use the Czech Labor Force Survey (LFS), a quarterly survey covering about 60,000 Czech individuals, for the years 1993-2000 and 2004-2013. The estimation sample consists of prime-age (25-55) women with at least one child. The sample size and the relevant descriptive statistics are all reported in Appendix Tables A.2 and A.3. As there is no information about the quarter or month of birth, the age of the youngest child is reported in completed years, e.g. children aged 2 are children older than 2 and under 3 years. LFS is a repeated cross-section with a 5 -quarter rotational panel structure but only a subset of households are followed for all 5 quarters. While the panel dimension allows construction of a more detailed measure of the child's age (in quarters of a year) when the reported age changes between the two consecutive quarters, this approach (used e.g. by Mullerova 2014 and Mullerova 2016) leads to a substantial reduction in the sample size and a possible measurement error due to imprecise reporting.

We define the economic status of women in the sample based on their selfreported status in the LFS data using the International Labour Organization (ILO) definition $^{35}$ but make one important adjustment. While the ILO sometimes treats

\footnotetext{
${ }^{35}$ According to this definition, an individual as unemployed if $\mathrm{s} /$ he does not have a job, is
} 
individuals on maternity and parental leave as employed, ${ }^{36}$ we always treat them as inactive in our analysis. In a country with a very long family leave and imperfect job protection, the formal attachment of mothers to their jobs is much weaker compared to countries where the leave is short and the likelihood of returning to ones job is close to one. Moreover, the ILO coding ignores the fact that individuals on leave (in contrast with those employed) do not acquire work experience and may actually lose some of their work skills. Maternity and parental leaves (even if job-protected) form (the first part of) career breaks after childbirth and are likely to have impact on mothers future labor market outcomes.

There is a strand of literature that questions the difference between unemployment and inactivity (Flinn and Heckman 1983, Gönül 1992, Benati 2001) and the usefulness of the ILO definition (Jones and Riddell 1999, Brandolini, Cipollone, and Viviano 2006). We argue that career breaks after childbirth represent a situation where the distinction between the two states is both meaningful and important for at least four reasons: First, the distinction helps us disentangle the initial period of paid family leave from the post-leave unemployment. ${ }^{37}$ Second, the social costs associated with the post-leave unemployment and post-leave inactivity substantially differ. Third, the post-leave unemployment signals a job loss and an (in)voluntary change of a job, whereas post-leave inactivity may, in principle, reflect a mothers' decision to prolong her family leave beyond the statutory duration and does not necessarily mean a job change. Fourth, in line with the test designed in the literature (Flinn and Heckman 1983), the limited transition information that we have suggests that the unemployment to employment transition is much more frequent

actively seeking a job, and is ready to start working within 2 weeks

${ }^{36}$ If a person has a formal attachment to his/her job, but is temporarily not at work because of the maternity/parental leave, ILO codes that person as employed.

${ }^{37}$ Post-leave unemployment is likely to have a more negative impact both on women's contemporaneous utility as well as on the quality of post-childbirth jobs (Francesconi 2002, Adda, Dustmann, and Stevens 2011) compared to the initial period of inactivity while on paid family leave. 
than the inactivity to employment transition both overall and, in particular among women with a child older than 4 (after the paid family leave). ${ }^{38}$

\section{Changes in Labor Market Status Profiles}

This section presents the non-employment and unemployment profiles of Czech mothers by the age of their youngest child over the two periods we study. Note that the shifts of these profiles over time capture the evolution of the outcome variables of our difference-in-differences analysis in Section 5.

\subsection{The 1995 Reform: Descriptive Evidence}

Figure 3 shows that the non-employment rate among women whose youngest child is 0 and 1 remained at almost 95\% over the entire 1993-1999 period, confirming the very high family leave take-up rate among Czech mothers with children younger than $2.3^{39}$

After the 1995 reform, the profiles moved upwards for all women with children aged 2 and older, but the most for women with a child aged 3. Starting at around $40 \%$ before the reform, the non-employment rate of women with a child aged 3 reached 64\% in 1996 and leveled around 70\% from 1997 onwards. Figure 4 reveals that a large part of the after-1995 increase in non-employment was driven by the rise in post-leave unemployment. The unemployment-to-population rate of women whose youngest child was aged 4 gradually increased from less than $10 \%$ in the prereform period to $26 \%$ in 1999 . The drop in the share of unemployed among women with a child aged 3 in the after-reform years is driven by the increasing absence of

\footnotetext{
${ }^{38}$ While $36 \%$ of unemployed women with a child aged 4-7 enter employment in the subsequent quarter, only $20 \%$ of inactive women with a child of the same age do (source: LFS data, average over 1993-2014).

${ }^{39}$ Note that the first 2 years of paid family leave were not affected by the reform.
} 
Figure 3: Female non-employment rate by the age of their youngest child, 1993-1999.

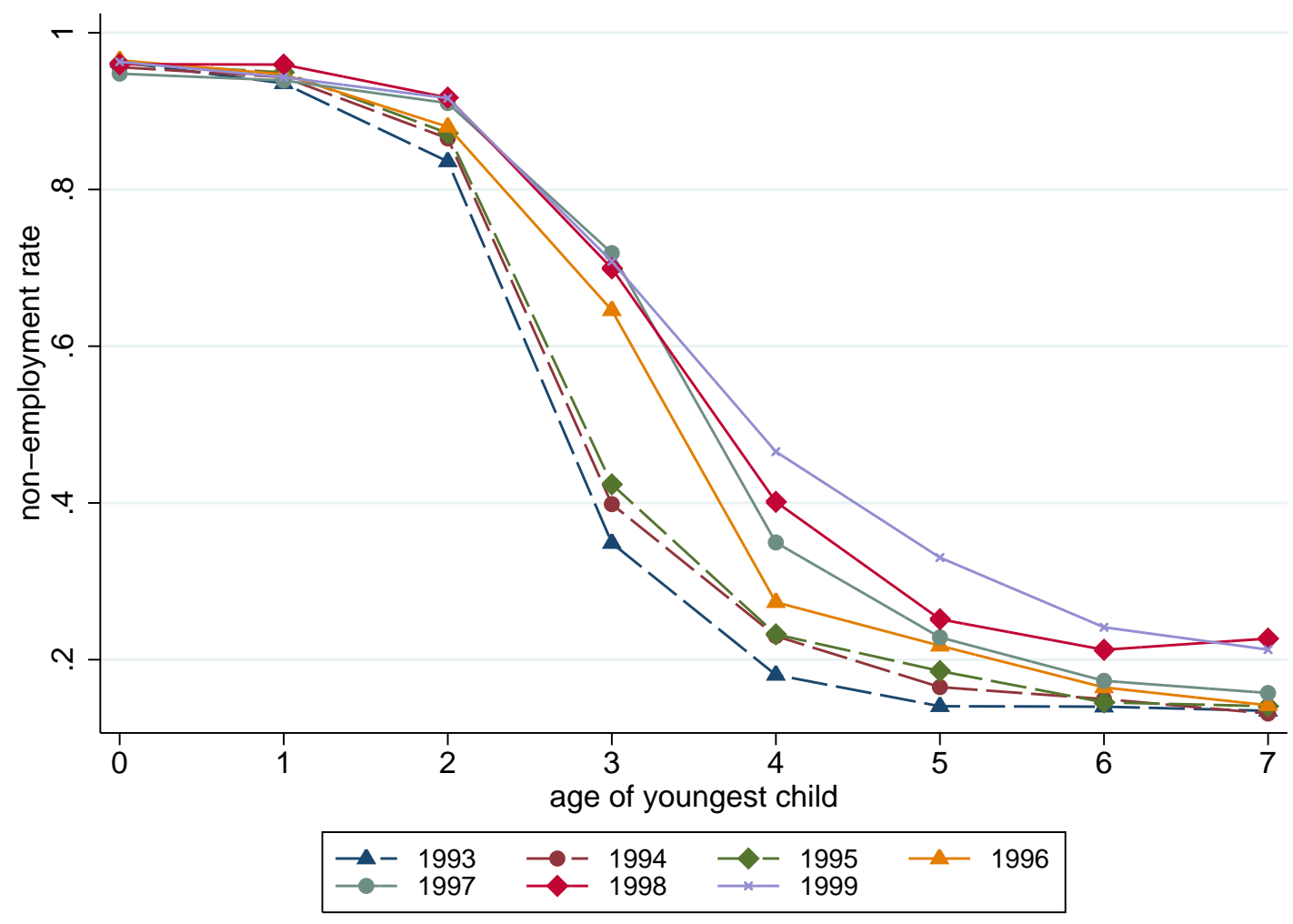

Note: The Figure illustrates the non-employment rate (share of inactive and unemployed in the population) for Czech women aged 25-54, by the age of their youngest child. The child's age is reported in years that the child had reached. Therefore, a child aged 3 is a child aged older than 3 and under 4 years, and therefore the mother of this child is no longer eligible for job protection. Source: Czech Labour Force Survey, 1993-1999.

these women from the labor force. ${ }^{40}$

\subsection{The 2008 Reform: Descriptive Evidence}

Figure 5 suggests that the overall shape of the non-employment profile for the prereform years (2004-2007) is very similar to the one shown in Figure 3 for 1996-1999. After the 2008 reform, the non-employment rate among mothers whose youngest

\footnotetext{
${ }^{40}$ Note that before the reform, the unemployment rate peaked among women whose youngest child was aged 3, the time when a majority of women returned from their leave to the labor force. As a result of the reform, this peak has shifted till the time when the child reaches 4 .
} 
Figure 4: Female unemployment-to-population rate by the age of their youngest child, 1993-1999.

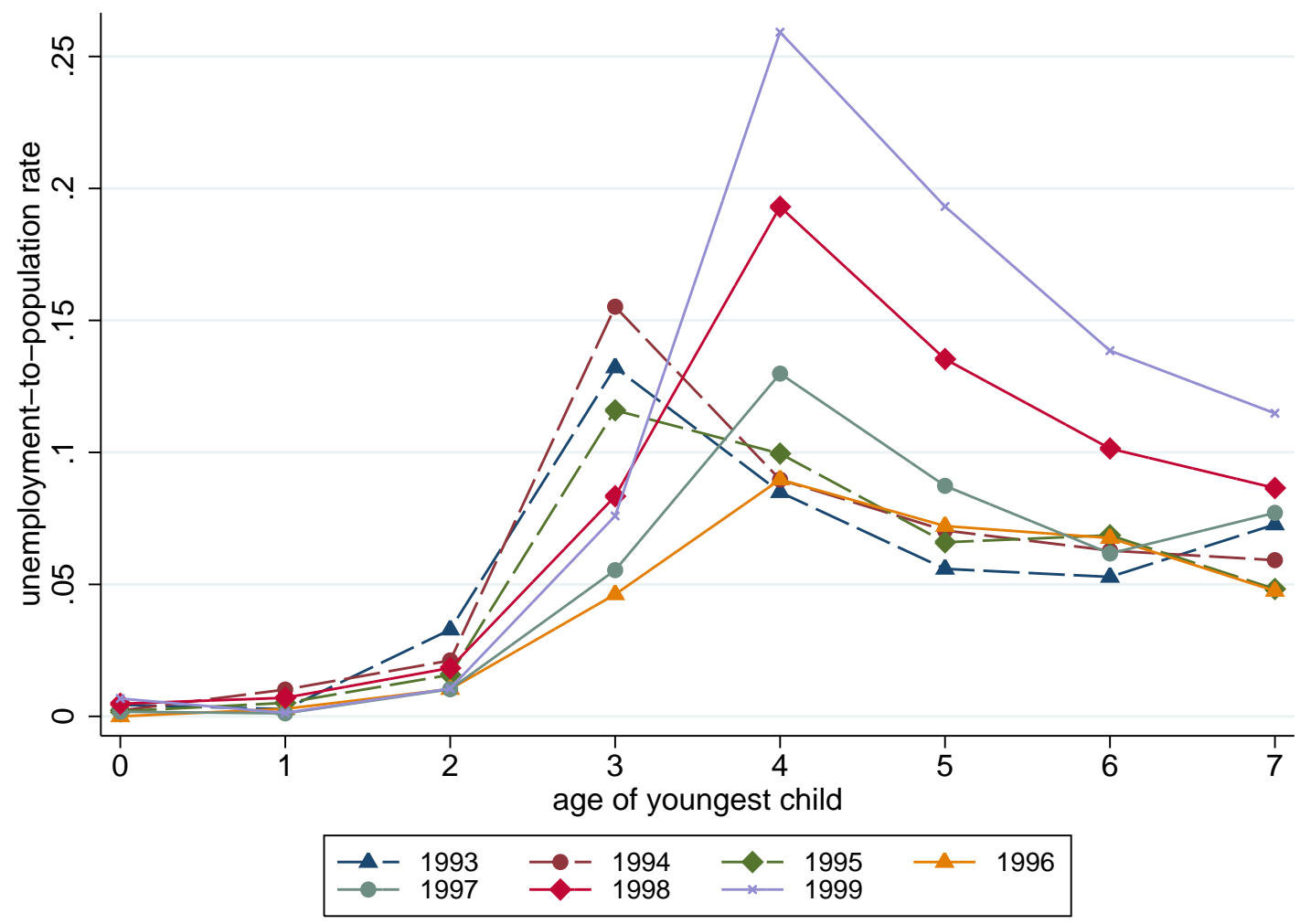

Note: The Figure illustrates the unemployment-to-population rate (share of unemployed in the population) for Czech women aged 25-54, by the age of their youngest child. The child's age is reported in years that the child had reached. Therefore, a child aged 3 is a child aged older than 3 and under 4 years, and therefore the mother of this child is no longer eligible for job protection. Source: Czech Labour Force Survey, 1993-1999.

child was 3 dropped from almost $70 \%$ in 2004-2007 to $60 \%$ in 2009 and further plummeted to less than 50\% in 2010-2013, suggesting that many eligible women shortened their paid leave from 4 to 3 years. ${ }^{41}$ Although the 2008 reform has also allowed women with sufficiently high pre-childbirth income to choose a 2-year track parental allowance, the data show no evidence that women were more likely to return

\footnotetext{
${ }^{41}$ The delay in the effects of the reform was caused by its design. The first women who took advantage of the flexible system returned to the labor market only in 2009 (for details, see Section 2.1).
} 
to work after 2 years on leave in the after-reform period than prior to the reform. ${ }^{42}$ Figure 5: Female non-employment rate by the age of their youngest child, 2004-2013.

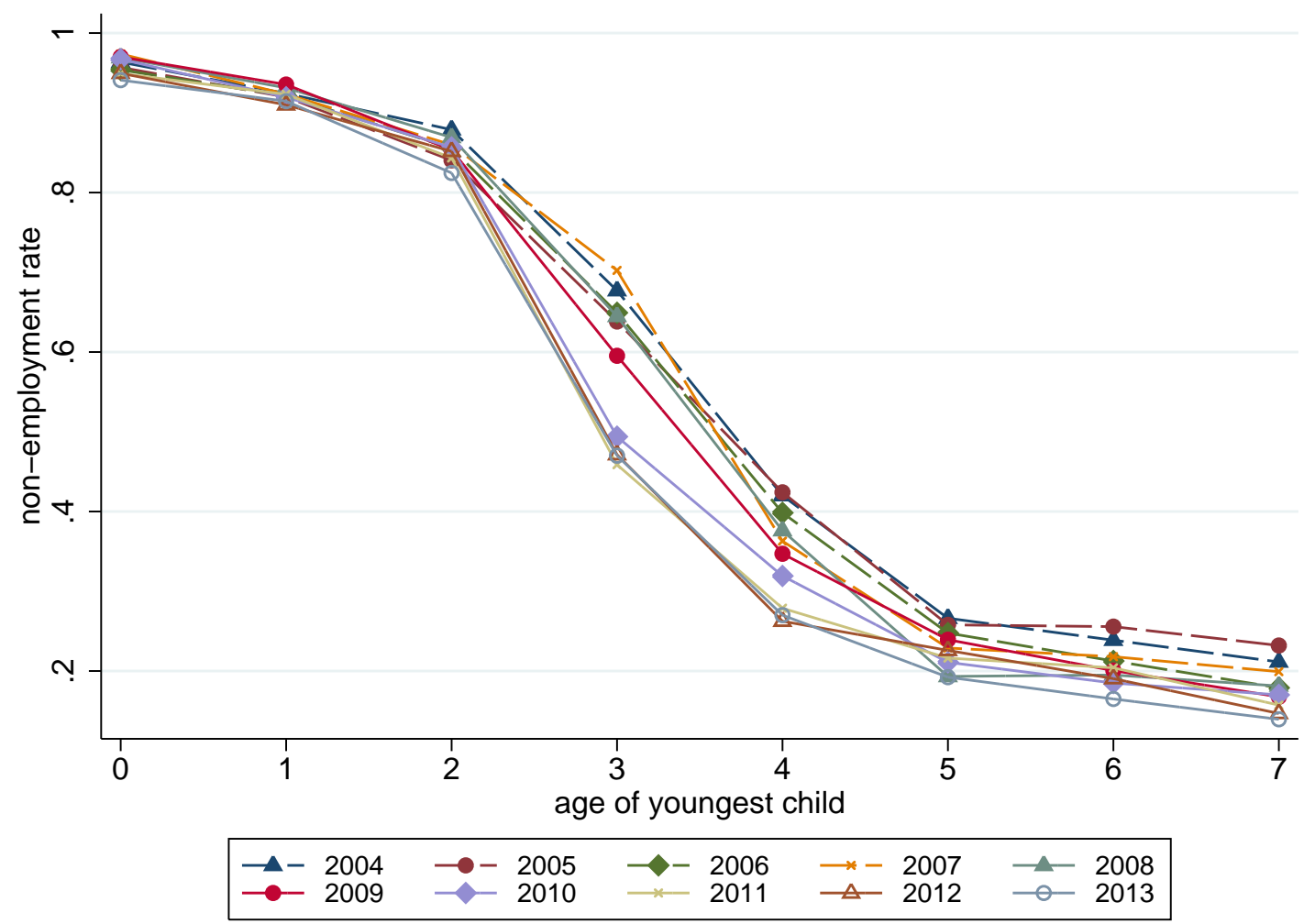

Note: The Figure illustrates the non-employment rate (share of inactive and unemployed in the population) for Czech women aged 25-54, by the age of their youngest child. The child's age is reported in years that the child had reached. Therefore, a child aged 3 is a child older than 3 and under 4 years, and therefore the mother of this child is no longer eligible for job protection. Source: Czech Labour Force Survey, 2004-2013.

Figure 6 reveals that the unemployment-to-population ratio increased substantially among women whose youngest child was 3 , the period immediately following the 3-year track of the allowance, suggesting that the decline in their inactivity (reflecting the choice of a leave shorter than the 4-year track) was even greater than suggested above by the drop in non-employment .

The presented profiles provide the first evidence on the impact of the two reforms.

\footnotetext{
${ }^{42}$ This is consistent with the statistics of the Czech Ministry of Labour and Social Affairs, which report that only $6 \%$ of women chose the 2 -year track in 2011.
} 
Figure 6: Female unemployment-to-population rate by the age of their youngest child, 2004-2013.

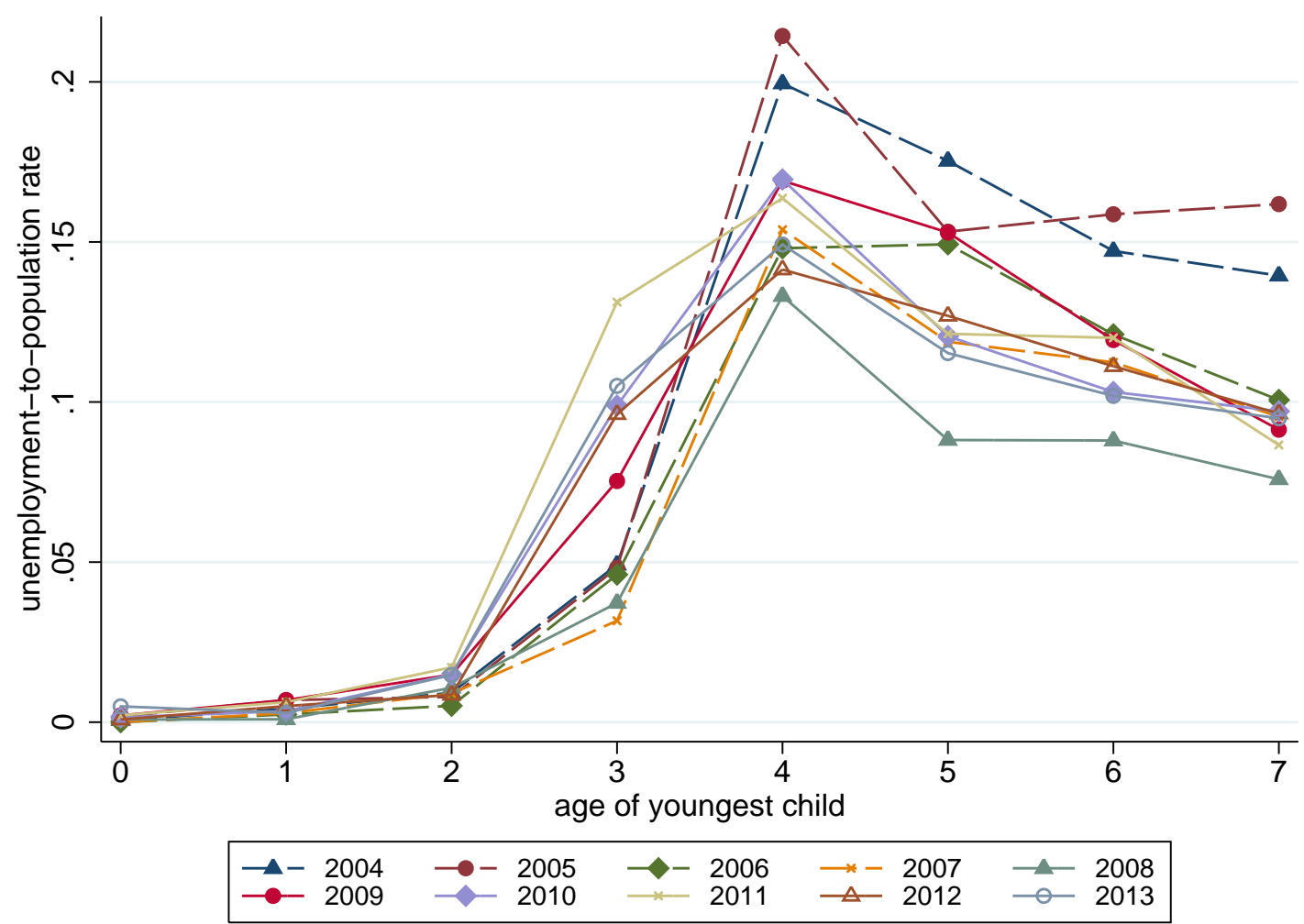

Note: The Figure illustrates the unemployment-to-population rate (share of unemployed in the population) for Czech women aged 25-54, by the age of their youngest child. The child's age is reported in years that the child had reached. Therefore, a child aged 3 is a child older than 3 and under 4 years, and therefore the mother of this child is no longer eligible for job protection. Source: Czech Labour Force Survey, 2004-2013.

However, they also capture the aggregate trends in the economy, in particular, the effect of the two crises that hit Czech labor market in 1997 and 2009. In order to filter out the aggregate conditions we use the difference-in-differences design with the control groups of women with older children to estimate the impact of the reforms in the next section. 


\section{$5 \quad$ Estimation Results}

\subsection{Baseline Specification}

In our baseline specification, we estimate the effect of the 1995 and 2008 reforms on mother's labor market status 2-7 years after childbirth using mothers with children 813 to control for aggregate trends in the labor market via the difference-in-differences design. ${ }^{43}$ Our findings, reported in Tables 1 and 2, confirm the patterns already discernible from the labor market status profiles presented in Section 4 .

The 1995 reform (which extended the parental allowance from 3 to 4 years) substantially increased the occurrence of non-employment among mothers with 3-6 year old children. Notably, the probability that a mother with a 3 year old child does not work increased by as much as 25.6 p.p. and the non-employment of mothers of 4 and 5 year olds rose by 11.5 and 4.9 p.p., respectively (see Panel A in Table 1). We observe no effect on women whose children had turned 7 .

Decomposition of the effect of the 1995 reform on non-employment into the effect on inactivity and on unemployment (Panels B and $\mathrm{C}$ of Table 1) reveals that the impact of the parental allowance extension on the overall career breaks after childbirth operated through the following channels: it raised the inactivity of women with children 2-4 and shifted the after-leave unemployment forward by two years (from when the youngest children were 2-3 to when they were 4-6). The impact of the 1995 reform on the probability that women with 3 year old children stayed at home was enormous: their inactivity rate increased by as much as 35.7 p.p. The fact that, in response to the 1995 reform, over one third of mothers of 3 year old children stayed on leave beyond the 3-year job protection period either implies that the monetary incentives of the family leave dominate the job security concerns, or

\footnotetext{
${ }^{43}$ Appendix Tables A.2 and A.3 show the summary statistics for the treatment and control groups, before and after the 1995 and 2008 reforms.
} 
Table 1: Results of the difference-in-differences estimation: 1995 reform

\begin{tabular}{|c|c|c|c|c|c|c|}
\hline \multicolumn{7}{|c|}{ Treatment group: women whose youngest child is: } \\
\hline & aged 2 & aged 3 & aged 4 & aged 5 & aged 6 & aged 7 \\
\hline & \multicolumn{6}{|c|}{ Panel A: impact on non-employment } \\
\hline \multirow[t]{2}{*}{ Treat*After } & 0.011 & $0.256^{* * *}$ & $0.115^{* * *}$ & $0.049^{* * *}$ & $0.018^{* *}$ & 0.011 \\
\hline & $(0.007)$ & $(0.016)$ & $(0.014)$ & $(0.007)$ & $(0.007)$ & $(0.007)$ \\
\hline R-squared & 0.444 & 0.232 & 0.104 & 0.079 & 0.072 & 0.069 \\
\hline \multirow[t]{2}{*}{ Observations } & 83549 & 83701 & 80879 & 68347 & 56513 & 44293 \\
\hline & \multicolumn{6}{|c|}{ Panel B: impact on inactivity } \\
\hline \multirow[t]{2}{*}{ Treat*After } & $0.047^{* * *}$ & $0.357^{* * *}$ & $0.065^{* * *}$ & $0.012^{* *}$ & 0.001 & 0.003 \\
\hline & $(0.008)$ & $(0.016)$ & $(0.006)$ & $(0.005)$ & $(0.004)$ & $(0.005)$ \\
\hline R-squared & 0.539 & 0.25 & 0.058 & 0.043 & 0.04 & 0.04 \\
\hline \multirow[t]{2}{*}{ Observations } & 83549 & 83701 & 80879 & 68347 & 56513 & 44293 \\
\hline & \multicolumn{6}{|c|}{ Panel C: impact on unemployment } \\
\hline Treat*After & $-0.037^{* * *}$ & $-0.100^{* * *}$ & $0.050^{* * *}$ & $0.038^{* * *}$ & $0.016^{* * *}$ & 0.008 \\
\hline & $(0.004)$ & $(0.006)$ & $(0.012)$ & $(0.007)$ & $(0.005)$ & $(0.005)$ \\
\hline R-squared & 0.039 & 0.042 & 0.06 & 0.053 & 0.049 & 0.047 \\
\hline Observations & 83549 & 83701 & 80879 & 68347 & 56513 & 44293 \\
\hline
\end{tabular}

Note: The treatment groups consist of prime-aged women (aged 25-55), whose youngest child is $2-7$. The control group consists of prime-aged women whose youngest child is 8-13. For each treatment group, a separate regression is estimated by the age of the youngest child, but the control group is fixed in all regressions. All regressions include dummies for the treatment group and after period, quarter-year dummies, quarter-year dummies interacted with level of education, and other control variables. The beginning of the after-period for the treatment group is set to the year when a mother of a child of a given age becomes affected by the reform. Standard errors (in parentheses) are clustered at the group-year level $\left(* \mathrm{p}<0.10,{ }^{* *} \mathrm{p}<0.05,{ }^{* * *} \mathrm{p}<0.01\right)$. Source: Czech LFS (1993-1999), own calculations.

it questions the actual strength of the job protection in the Czech Republic. ${ }^{44}$ The change in the parental leave policy might have also set a new social norm appealing to mothers to spend more time at home rearing their children. ${ }^{45}$ Unfortunately, with our data, we are not able to disentangle which of these factors was the most important in explaining the observed change in women's behavior.

As for mothers with children aged 4, the effect of the 1995 reform on non-

\footnotetext{
${ }^{44}$ We discussed some evidence of weak job protection in Section 2.1.

${ }^{45}$ The 1995 reform was accompanied by a media campaign highlighting the benefits of mothers staying at home with their child.
} 
employment was a combination of an increase in post-leave inactivity (6.5 p.p.) and post-leave unemployment (5.0 p.p.). For mothers of older children (aged 5 and 6), the increase in non-employment was entirely driven by a rise in unemployment. The occurrence of inactivity and of unemployment among women with a child of 7 or more seems again unaffected by the reform.

As expected, the impact of the 2008 reform (which offered some women to receive the same total amount of parental leave allowance over a shorter period of 2 or 3 years) was opposite to that of the 1995 reform but smaller. Panel A in Table 2 shows that the option to reduce the duration of paid parental leave led to a decrease in non-employment by 14.7 and 8.0 p.p. of mothers of 3 and 4 year old children, respectively. At the same time, it raised the probability of non-employment of mothers of 2 year old children by 2.9 p.p.

These results can again be explained by the "trade-off" between mothers inactivity and unemployment. Panels B and C of Table 2 reveal that the 2008 reform reduced the probability of inactivity of women with 3 and 4 year old children by as much as 22.4 and 7.4 p.p., respectively, but had almost no impact on other mothers. The observed reduction in inactivity of women with 3 year old children was partly counteracted by a rise in the likelihood of unemployment (by 7.7 p.p.). The occurrence of unemployment among mothers of 2 year old children increased by 2.8 p.p. The flexible parental allowance schedule clearly induced some eligible mothers to take shorter family leave and to return to labor force earlier, shifting their postleave unemployment backward to the time when their children were already 2 or 3. 46

\footnotetext{
${ }^{46}$ The zero impact on unemployment of mothers of 4 year old children may be driven by two opposite factors. While those women who shortened their leave to 2 or 3 years were probably more likely to find a job before their child turned 4 (decreasing their likelihood of unemployment), women who shortened their post-leave inactivity to 4 years (as reflected by the drop in inactivity of mothers of 4 year old children) were more likely to return to the labor market as unemployed. Next section provides further evidence on the heterogeneity of the impact of the two reforms by education.
} 
Table 2: Results of the difference-in-differences estimation: 2008 reform

\begin{tabular}{|c|c|c|c|c|c|c|}
\hline \multicolumn{7}{|c|}{ Treatment group: women whose youngest child is: } \\
\hline & aged 2 & aged 3 & aged 4 & aged 5 & aged 6 & aged 7 \\
\hline & \multicolumn{6}{|c|}{ Panel A: impact on non-employment } \\
\hline Treat*After & $\begin{array}{c}0.029 * * * \\
(0.006)\end{array}$ & $\begin{array}{c}-0.147^{* * *} \\
(0.013)\end{array}$ & $\begin{array}{c}-0.080^{* * * *} \\
(0.007)\end{array}$ & $\begin{array}{c}-0.010^{*} \\
(0.006)\end{array}$ & $\begin{array}{c}-0.019^{* * *} \\
(0.006)\end{array}$ & $\begin{array}{c}-0.040^{* * *} \\
(0.006)\end{array}$ \\
\hline R-squared & 0.456 & 0.243 & 0.14 & 0.117 & 0.118 & 0.115 \\
\hline \multirow[t]{2}{*}{ Observations } & 86228 & 75829 & 66997 & 58713 & 51286 & 43896 \\
\hline & \multicolumn{6}{|c|}{ Panel B: impact on inactivity } \\
\hline Treat*After & $\begin{array}{c}0.001 \\
(0.005)\end{array}$ & $\begin{array}{c}-0.224^{* * *} \\
(0.016)\end{array}$ & $\begin{array}{c}-0.074^{* * *} \\
(0.007)\end{array}$ & $\begin{array}{c}0.004 \\
(0.005)\end{array}$ & $\begin{array}{l}-0.006 \\
(0.005)\end{array}$ & $\begin{array}{c}-0.015^{* * *} \\
(0.004)\end{array}$ \\
\hline R-squared & 0.589 & 0.28 & 0.067 & 0.045 & 0.044 & 0.044 \\
\hline \multirow{2}{*}{ Observations } & 86228 & 75829 & 66997 & 58713 & 51286 & 43896 \\
\hline & \multicolumn{6}{|c|}{ Panel C: impact on unemployment } \\
\hline Treat*After & $\begin{array}{c}0.028^{* * *} \\
(0.004)\end{array}$ & $\begin{array}{c}0.077^{* * *} \\
(0.005)\end{array}$ & $\begin{array}{l}-0.006 \\
(0.007)\end{array}$ & $\begin{array}{c}-0.014^{* * *} \\
(0.004)\end{array}$ & $\begin{array}{c}-0.013^{* *} \\
(0.005)\end{array}$ & $\begin{array}{c}-0.024^{* * *} \\
(0.007)\end{array}$ \\
\hline R-squared & 0.077 & 0.066 & 0.085 & 0.085 & 0.089 & 0.088 \\
\hline Observations & 86228 & 75829 & 66997 & 58713 & 51286 & 43896 \\
\hline
\end{tabular}

Note: The treatment groups consist of prime-aged women (aged 25-55), whose youngest child is 2-7. The control group consists of prime-aged women whose youngest child is 8-13. For each treatment group, a separate regression is estimated by the age of the youngest child, but the control group is fixed in all regressions. All regressions include dummies for the treatment group and after period, quarter-year dummies, quarter-year dummies interacted with level of education, and other control variables. The beginning of the after-period for the treatment group is set to the year when a mother of a child of a given age becomes affected by the reform. Standard errors (in parentheses) are clustered at the group-year level $\left(* \mathrm{p}<0.10,{ }^{* *} \mathrm{p}<0.05,{ }^{* * *} \mathrm{p}<0.01\right)$. Source: Czech LFS (2004-2013), own calculations.

A subset of our baseline results is directly comparable with the estimates from Mullerova (2014) and Mullerova (2016) who use an alternative difference-in-differences approach described earlier. In particular, Mullerova (2014) finds that the employment probability of mothers of 3-year old children fell by 23 p.p. after the 1995 reform, which is very close to our estimate of 25.6 p.p. increase in the likelihood of non-employment in the same group. Similarly, Mullerova's estimates of the impact of the 2008 reform on mothers of three-year old children (Mullerova 2016) differ from the relevant subset of our results by less than 3 p.p. The similarity of the 
comparable estimates suggests that our findings are not driven by the particular choice of identification strategy.

We have so far presented our estimates of the effect of the two reforms for groups of mothers defined by the age of their youngest child. Assuming constant birth rate within each of the two estimation periods, ${ }^{47}$ we can summarize the overall impact of the reforms (on all groups of mothers with young children together) by simply comparing the average pre-reform labor market status rates with the average after-reform labor market status rates as predicted by our differences-in-differences estimates. $^{48}$

In particular, we focus on the overall effects on mothers with children younger than 8 and on the unintended effects on mothers post-leave labor market status, and find the following: The 1995 reform increased the non-employment rate among mothers with children younger than 8 from $47 \%$ to $53 \%$. The non-employment among mothers of children aged 4-7 went up from $16 \%$ to $21 \%$, with an increase in post-leave unemployment from $7 \%$ to $10 \%$ and a rise in post-leave inactivity from 9\% to 11\%. The 2008 reform achieved only a partial reversal of the effect of the 1995 reform and reduced the non-employment rate among mothers with children younger than 8 from $56 \%$ to $53 \%$. In terms of the unintended consequences, the non-employment among mothers with children 4-7 declined from $27 \%$ to $23 \%$, with a decrease in unemployment from $15 \%$ to $13 \%$ and in post-leave inactivity from $12 \%$ to $10 \%$. As the 2008 reform offered subset of eligible mothers to spread the same amount of total allowance over only 2 or 3 years, we observe a corresponding decrease

\footnotetext{
${ }^{47}$ While the birth rate was indeed not constant over the two analyzed periods, it always moved in the opposite direction than the length of the statutory parental leave (as shown in Appendix Figure A.1), i.e. in the direction that biases our results towards zero. These "aggregated" results (presented below) should be therefore also regarded as a lower bound of the true effects.

${ }^{48}$ In particular, we predict the after-reform non-employment (unemployment or inactivity) rate for each child-age category by adding the respective differences-in-differences estimates from Tables 1 and 2 to the corresponding pre-reform non-employment (unemployment or inactivity) rate (as shown in Appendix Tables A.2 and A.3). Assuming a constant birth rate, we then "aggregate" the pre- and after-reform non-employment (unemployment or inactivity) rate for a subgroup of women with young children by averaging the respective rates for each of the child-age categories.
} 
in inactivity among mothers of 2 and 3 year old from $73 \%$ to $62 \%$ after 2008 . This decline was again accompanied by an unintended rise in post-leave unemployment from $3 \%$ to $8 \%$, resulting in a drop in non-employment by only 6 p.p.

\subsection{Results by Education}

One may expect the monetary incentives of the family leave to be of greater concern for lower-income mothers and the job protection to be more important for mothers with higher earnings potential and steeper labor market careers (Lalive and Zweimüller (2009)). This would imply a greater impact of the reforms of the duration of the parental allowance on lower-income mothers. We explore the potential heterogeneity in mothers' responses to the two reforms next. As income is not available in our data, we use the best proxy we have and estimate our baseline specification separately by two levels of education, ${ }^{49}$ low and high, defined by woman's successful completion of high school. ${ }^{50}$ Before we discuss the estimation results by education, we note that low- and high-educated mothers do not differ too much in terms of the use of parental leave (see Table 3). The differences in the non-employment rate between these two groups are driven to a great extent by a different likelihood of unemployment, which is twice as high (three times as high) among the low-educated when compared to the high-educated prior to the 1995 (2008) reform.

The estimation results by education confirm that the changes in the duration of the parental allowance affected the low-educated (i.e. low-income) mothers more than the high-educated, but the differences are relatively small. While the 1 year

\footnotetext{
${ }^{49}$ Education as the key determinant in wage regressions serves also as a proxy for husband's income, given the well-documented evidence of assortative mating (see for example Pencavel 1998).

50 'Low-educated' corresponds to the ISCED 3 level with apprenticeship certificate, but without school leaving examination, or lower level of education (corresponding to less than A levels in the UK, without a Baccalaureate in France or without a high-school diploma in the US). Finer classification using ISCED renders a too small sample size for some of the groups.
} 
Table 3: Summary statistics by woman's education

\begin{tabular}{r|cc|cc|cc|cc}
\hline \hline & \multicolumn{4}{|c|}{1995 reform } & \multicolumn{4}{c}{2008 reform } \\
& \multicolumn{2}{|c|}{ High education } & \multicolumn{2}{|c|}{ Low education } & \multicolumn{2}{|c}{ High education } & Low education \\
& Before & After & Before & After & Before & After & Before & After \\
\cline { 2 - 10 } Non-employed & 0.269 & 0.345 & 0.353 & 0.486 & 0.393 & 0.363 & 0.534 & 0.487 \\
Inactive & 0.215 & 0.284 & 0.258 & 0.371 & 0.334 & 0.305 & 0.377 & 0.341 \\
Unemployed & 0.053 & 0.061 & 0.095 & 0.115 & 0.059 & 0.059 & 0.157 & 0.147 \\
Observations & 14477 & 22268 & 13783 & 21149 & 18497 & 30948 & 15122 & 19174 \\
\hline \hline
\end{tabular}

Notes: The sample includes all treated women, i.e. women whose youngest child is 2-7. High education corresponds to ISCED 3 level with school leaving examination or more, while low education is defined as ISCED 3 level with apprenticeship certificate (but without school leaving examination) or less. The before period for the 1995 reform is defined as 1993 Q1-1995 Q3 and the after period as 1995 Q4-1999 Q4. The before period for the 2008 reform covers 2004-2007 and the after period 2008-2013. Source: Czech LFS (1993-2013), own calculations.

extension of parental allowance in 1995 raised the probability of being inactive among low-educated women whose youngest child is 3 by 41 p.p., the increase among the high-educated women was 30 p.p. (see Panel B of Table 4). ${ }^{51}$ Similarly, the inactivity of mothers whose youngest child was 3 dropped somewhat more for the low-educated (24 p.p.) than for the high-educated (20 p.p.) in response to the 2008 reform (see Panel B of Table 5). While these results support the conjecture (presented in Lalive and Zweimüller (2009)) that monetary incentives of parental leave matter more to low-income mothers, it shows little evidence on the importance of job protection to high-income mothers: The results suggest that the 1995 reform induced almost one third of high-educated mothers to forfeit job protection and stay on leave beyond their child's third birthday. Again, whether this reflects ineffective job protection or the dominance of the impact of the family policy as a social norm cannot be addressed in our data.

Not surprisingly, the impact on unemployment (shifting the risk of unemployment to the time when the child turns 4 after the 1995 reform, and increasing unemployment of mothers with 2 and 3 year old children after the 2008 reform) was

\footnotetext{
${ }^{51}$ The reform, however, also induced high-educated mothers with 2 year old children to be more inactive than the low-educated.
} 
Table 4: Difference-in-differences estimation by education: 1995 reform

\begin{tabular}{|c|c|c|c|c|c|c|}
\hline & \multicolumn{6}{|c|}{ Treatment group: women whose youngest child is } \\
\hline & aged 2 & aged 3 & aged 4 & aged 5 & aged 6 & aged 7 \\
\hline & \multicolumn{6}{|c|}{ Panel A: impact on non-employment } \\
\hline \multirow{4}{*}{ Treat*After*HighEduc } & $-0.015^{*}$ & $0.287^{* * *}$ & $0.098^{* * *}$ & $0.050^{* * *}$ & $0.046^{* * *}$ & $0.035^{* * *}$ \\
\hline & $(0.008)$ & $(0.014)$ & $(0.018)$ & $(0.009)$ & $(0.010)$ & $(0.011)$ \\
\hline & $0.050^{* * *}$ & $-0.062^{* * *}$ & $0.034^{* *}$ & -0.001 & $-0.055^{* * *}$ & $-0.047 * * *$ \\
\hline & $(0.015)$ & $(0.010)$ & $(0.016)$ & $(0.009)$ & $(0.014)$ & $(0.011)$ \\
\hline \multirow{3}{*}{$\begin{array}{r}\text { R-squared } \\
\text { Observations }\end{array}$} & 0.444 & 0.232 & 0.104 & 0.079 & 0.072 & 0.07 \\
\hline & 83549 & 83701 & 80879 & 68347 & 56513 & 44293 \\
\hline & \multicolumn{6}{|c|}{ Panel B: impact on inactivity } \\
\hline \multirow{4}{*}{ Treat*After*HighEduc } & $0.029^{* * *}$ & $0.412^{* * *}$ & $0.057^{* * *}$ & $0.014^{*}$ & 0.008 & -0.002 \\
\hline & $(0.008)$ & $(0.016)$ & $(0.009)$ & $(0.007)$ & $(0.005)$ & $(0.009)$ \\
\hline & $0.035^{* *}$ & $-0.111^{* * *}$ & 0.016 & -0.004 & -0.013 & 0.009 \\
\hline & $(0.013)$ & $(0.013)$ & $(0.010)$ & $(0.008)$ & $(0.008)$ & $(0.010)$ \\
\hline R-squared & 0.539 & 0.252 & 0.058 & 0.043 & 0.04 & 0.04 \\
\hline \multirow{2}{*}{ Observations } & 83549 & 83701 & 80879 & 68347 & 56513 & 44293 \\
\hline & \multicolumn{6}{|c|}{ Panel C: impact on unemployment } \\
\hline \multirow{4}{*}{ Treat*After*HighEduc } & $-0.044^{* * *}$ & $-0.125^{* * *}$ & $0.041^{* *}$ & $0.036^{* * *}$ & $0.038^{* * *}$ & $0.036^{* * *}$ \\
\hline & $(0.007)$ & $(0.006)$ & $(0.015)$ & $(0.010)$ & $(0.009)$ & $(0.008)$ \\
\hline & $0.015^{* *}$ & $0.049^{* * *}$ & 0.018 & 0.004 & $-0.043^{* * *}$ & $-0.056^{* * *}$ \\
\hline & $(0.006)$ & $(0.011)$ & $(0.012)$ & $(0.009)$ & $(0.010)$ & $(0.007)$ \\
\hline R-squared & 0.04 & 0.042 & 0.06 & 0.053 & 0.05 & 0.047 \\
\hline Observations & 83549 & 83701 & 80879 & 68347 & 56513 & 44293 \\
\hline
\end{tabular}

Note: The treatment groups consist of prime-aged women (aged 25-55), whose youngest child is 2-7. The control group consists of prime-aged women whose youngest child is 8-13. For each treatment group, a separate regression is estimated by the age of the youngest child, but the control group is fixed in all regressions. All regressions include dummies for the treatment group and after period, quarter-year dummies, quarter-year dummies interacted with level of education, and other control variables. The beginning of the after-period for the treatment group is set to the year when a mother of a child of a given age becomes affected by the reform. Standard errors (in parentheses) are clustered at the group-year level $\left({ }^{*} \mathrm{p}<0.10,{ }^{* *} \mathrm{p}<0.05,{ }^{* * *} \mathrm{p}<0.01\right)$. Source: Czech LFS (1993-1999), own calculations.

always greater for the low-educated mothers (see Panel $\mathrm{C}$ in Tables 4 and 5).

In sum, the two reforms affected the total career breaks of low-educated mothers somewhat more than high-educated mothers due to higher impact on the family leave duration, as well as the subsequent unemployment. ${ }^{52}$ The smaller differences

\footnotetext{
${ }^{52}$ Somewhat surprisingly, the overall effect of the 1995 reform on non-employment was somewhat
} 
in the impact of the 2008 reform across the two education groups are in line with the fact that mothers with low pre-birth income (with the 4-year track as their only option) were not directly affected by the 2008 reform.

Table 5: Difference-in-differences estimation by education: 2008 reform

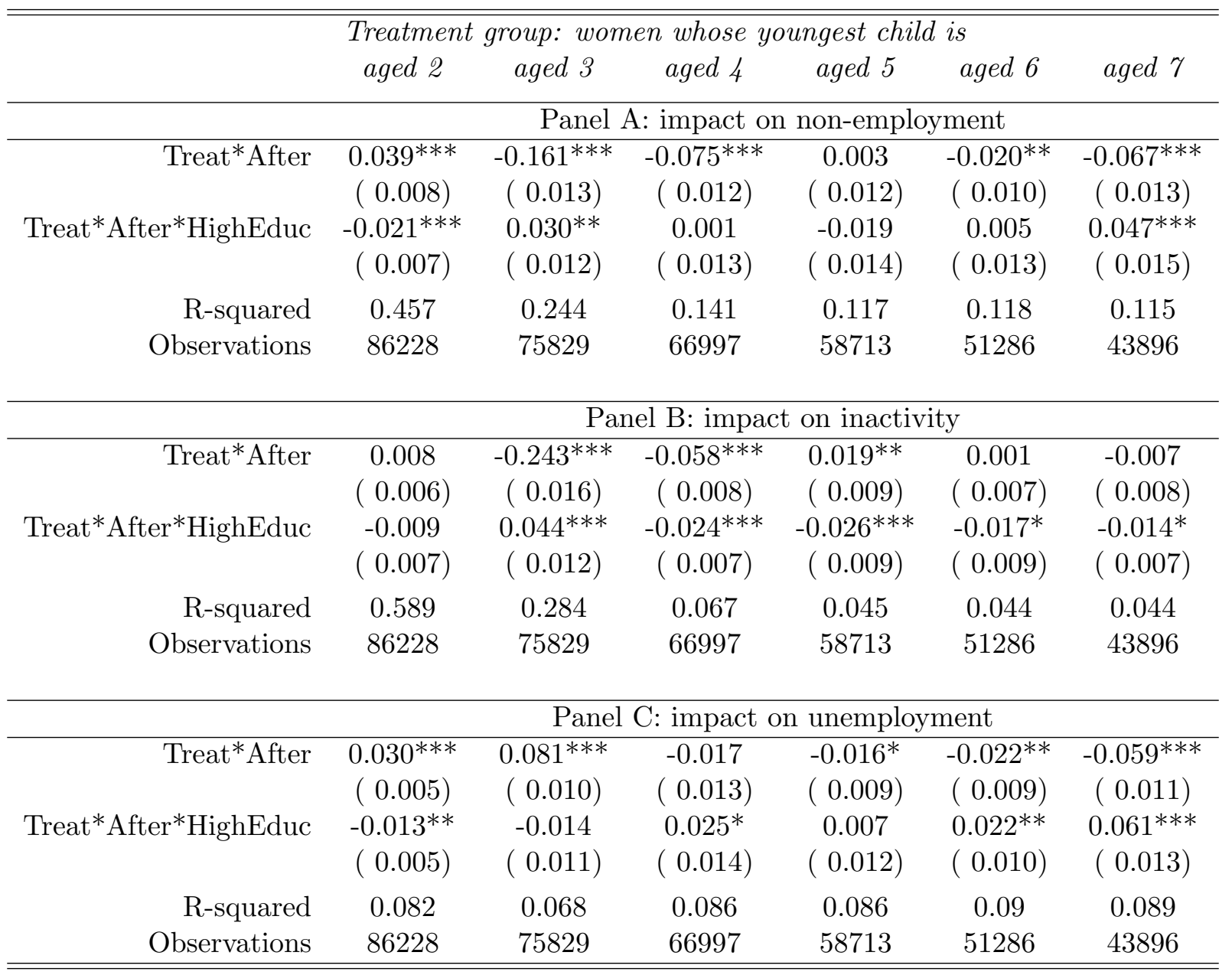

Note: The treatment groups consist of prime-aged women (aged 25-55), whose youngest child is $2-7$. The control group consists of prime-aged women whose youngest child is 8-13. For each treatment group, a separate regression is estimated by the age of the youngest child, but the control group is fixed in all regressions. All regressions include dummies for the treatment group and after period, quarter-year dummies, quarter-year dummies interacted with level of education, and other control variables. The beginning of the after-period for the treatment group is set to the year when a mother of a child of a given age becomes affected by the reform. Standard errors (in parentheses) are clustered at the group-year level $\left({ }^{*} \mathrm{p}<0.10,{ }^{* *} \mathrm{p}<0.05,{ }^{* * *} \mathrm{p}<0.01\right)$. Source: Czech LFS (2004-2013), own calculations.

Interestingly, the impact of the two reforms by education level reveals some greater among the high-educated mothers of 4 year old children, but the impact on inactivity and unemployment are not statistically different across education levels. 
evidence of the existence of long-term effects (on mothers with children 7 year old) among low-educated mothers, not discernible from the baseline results: The 1995 reform increased the probability of unemployment of low-educated mothers whose youngest child is 7 by 3.6 p.p. ${ }^{53}$ while the 2008 reform reduced their probability of unemployment by 6 p.p.

\subsection{Robustness Analysis}

This section presents several robustness checks of our baseline results. The control group in the baseline specification is defined by the age of the youngest child and thus includes different cohorts of women at different points in time. The baseline specification therefore assumes away any potential long-term effects of parental leave reforms that affected the mothers in the control group during the first years after their children were born. If such effects exist, the control group at the beginning of the period of interest might include women affected by different family leave policies than those who are in the control group at the end of the period.

The first robustness check for both reforms therefore uses an alternative control group comprised of earlier cohorts (mothers with older children), who experienced no reforms and thus were all exposed to the same family leave policies: women whose youngest child was 13-23 around the 1995 reform and women whose youngest child was 18-25 around the 2008 reform. ${ }^{54}$ The results of the first robustness check (for nonemployment) are presented in Appendix Table A.4. The baseline results are largely confirmed. ${ }^{55}$ The robustness check for the 1995 reform implies somewhat

\footnotetext{
${ }^{53} \mathrm{We}$ found no significant impact on inactivity, which is in contrast with Schönberg and Ludsteck (2014), where a similar reform induced about $4 \%$ of women to remain out of the labor force by the time their child is 6 .

${ }^{54}$ Women in the alternative control group for the 1995 reform have a youngest child born between 1970 and 1985-the period during which no major reform of parental leave took place. Women in the alternative control group for the 2008 reform gave birth to their youngest child between 1979 and 1992, i.e. in the pre-1995 parental allowance system.

${ }^{55}$ The same holds for the results for the other two outcomes (inactivity and unemployment) available upon request.
} 
greater impact of the reform on non-employment and reveals evidence supporting the long-term effects in the form of a 4.9 p.p. increase in the non-employment of mothers with children aged 7 (see Table A.4). The robustness check for the 2008 reform suggests an even greater reduction in the probability of non-employment for mothers with children aged 3 to 7 compared to the baseline results (see Table A.4). Our baseline specifications therefore provide more conservative estimates of the main effects of the two reforms than implied by the sensitivity analysis. ${ }^{56}$

Second, we conduct two robustness checks for the 2008 reform that take into account the potential effects of 2007 and 2011 changes in parental allowance as described in Section 2.1. We filter out the possible confounding effect of the 2007 change by excluding mothers, who had a child aged 0-3 in 2007 and could have thus collected the parental allowance in 2007 . Note that this substantially reduces the size of our treatment group and precludes the estimation of the impact on women with children aged 6 and 7. To filter out the potential impact of the 2011 change in parental allowance, we exclude women, who had a child younger than 2 at the beginning of 2011 or later and could have thus been affected by the 2011 decrease in the parental allowance.

Appendix Table A.5 shows the sensitivity of our results to the 2007 and 2011 changes in parental allowance. Again, our main findings are largely confirmed. The robustness check for the 2007 reform implies somewhat higher effect on nonemployment of mothers with children aged 2, 3, 4 and in particular 5. The robustness for the 2011 reform suggests somewhat smaller impact of the 2008 reform on nonemployment of mothers with children aged 3 .

\footnotetext{
${ }^{56}$ We conjecture that the relatively small dissimilarities are mainly driven by the fact that mothers with older children (who constitute the alternative control group) differ more substantially from both our treatment as well as our baseline control group in terms of lower sensitivity of their labor market outcomes to changes in the economy. The evolution of the labor market status of mothers in the two alternative control groups, however, is basically parallel to the baseline control groups evolution over the two periods that we study (figures are available upon request).
} 


\section{Conclusion}

This paper examines the impact of the duration of paid family leave on the labor market status of women 2-7 years after childbirth, using two reforms of parental leave allowance in the Czech Republic in 1995 and 2008. While the 1995 reform increased the allowance duration from 3 to 4 years, the 2008 reform allowed subset of eligible women to receive the same total amount of allowance over 2 or 3 years. As the two reforms have not altered the job protection period of three years, our results capture solely the impact of the monetary incentives of the paid family leave.

We extend the previous literature along several dimensions. First, we estimate the impact of changes in paid family leave longer than 2 years in a country with a very high family leave take-up rate, but strong overall attachment of women to the labor market. Second, we consider not only the post-birth non-employment, but also distinguish between mothers who are inactive and those who are unemployed. Third, we estimate the effect of the reforms by the age of mothers youngest child for children aged 2-7. This allows us to separate the intended effects of the reforms on mothers paid family leave take-up from the unintended effects the reforms had on post-leave unemployment and inactivity.

The most striking result of our estimation by the age of the youngest child shows that in response to the 1995 reform, an additional $36 \%$ of mothers of 3 year olds extended their family leave beyond the 3-year job protection period. Whether this implies a greater importance of the monetary aspect of paid family leave over job security, questions the effective strength of job protection in the Czech Republic, or suggests that family leave policy can set social norms that are stronger than the economic incentives needs to be answered by future research.

In terms of the structure of the overall career breaks after childbirth, the 1995 reform on average prolonged the family leave that women take beyond 3 years and 
shifted the post-leave unemployment spell until the child is older than 4 . The 2008 reform, on the other hand, shortened the family leave and raised the occurrence of post-leave unemployment among women with children aged 2-3. The comparable subset of our estimates is similar to the results of Mullerova (2014) and Mullerova (2016) suggesting that our findings are robust to wider range of identification strategies.

Overall, the 1995 reform increased the non-employment rate among mothers with children younger than 8 from $47 \%$ to 53\%. The 2008 reform, on the other hand, reduced the non-employment rate among mothers with children younger than 8 from $56 \%$ to $53 \%$. As for the unintended effects of the two reforms, captured by the labor force status of mother of children aged 4-7, the occurrence of postleave unemployment went up from $7 \%$ to $10 \%$ and that of post-leave inactivity from $9 \%$ to $11 \%$ in response to the 1995 reform. The 2008 reform led to a decrease in unemployment from $15 \%$ to $13 \%$ and in inactivity from $12 \%$ to $10 \%$ among mothers of children aged 4-7. While the inactivity among mothers of 2 and 3 year old children decreased from $73 \%$ to $62 \%$ after 2008 , the occurrence of unemployment went up from $3 \%$ to $8 \%$. The decline in the occurrence of unemployment among mothers with children 4-7 was therefore more than offset by the rise in the occurrence of unemployment among those with children 2-3 after 2008. As pointed in Lalive et al. (2014), shorter family leaves may increase the incentives of women to participate in other social programs such as unemployment insurance. On the other hand, longer family leaves result in higher skill depreciation that further lowers the chances of finding a job. Collection of much needed duration data on the exact post-birth history of Czech mothers would allow future research to quantify the impact of the reforms on the actual length of paid family leave and the subsequent post-leave unemployment or inactivity spells. 


\section{References}

Adda, J., C. Dustmann, and K. Stevens. 2011. "The career costs of children." CEPR Discussion Papers, No. $869 \%$.

Anderson, D. J., M. Binder, and K. Krause. 2002. "The motherhood wage penalty: Which mothers pay it and why?" American Economic Review 92 (2): 354-358.

Baker, M., and K. Milligan. 2008. "How does job-protected maternity leave affect mothers' employment?" Journal of Labor Economics 26 (4): 655-691.

- 2010. "Evidence from Maternity Leave Expansions of the Impact of Maternal Care on Early Child Development." Journal of Human Resources 45 (1): $1-32$.

Baum, C. L. 2003. "The effect of state maternity leave legislation and the 1993 Family and Medical Leave Act on employment and wages." Labour Economics 10 (5): $573-596$.

Benati, L. 2001. "Some empirical evidence on the 'discouraged worker' effect." Economics Letters 70 (3): 387-395.

Bergemann, A., and R. T. Riphahn. 2015. "Maternal employment effects of paid parental leave." IZA Discussion Paper, No. 9073, p. 47.

Berger, L. M., and J. Waldfogel. 2004. "Maternity leave and the employment of new mothers in the United States." Journal of Population Economics 17 (2): $331-349$.

Bičáková, A. 2012. "Gender unemployment gaps in the EU: Blame the family." CERGE-EI Working Paper no. 475, p. 44.

Blau, F. D., and L. M. Kahn. 2006. "The U.S. gender pay gap in the 1990s: Slowing convergence." ILR Review 60 (1): 45-66. 
. 2016. "The Gender Wage Gap: Extent, Trend, and Explanations." NBER Working Paper No. 21913.

Brandolini, A., P. Cipollone, and E. Viviano. 2006. "Does the ILO definition capture all unemployment?" Journal of the European Economic Association 4 (1): 153-179.

Carneiro, P., K. V. Loken, and K. G. Salvanes. 2015. "A flying start? Maternity leave benefits and long run outcomes of children." Journal of Political Economy $123(2): 365-412$.

Dahl, G. B., K. V. Løken, M. Mogstad, and K. V. Salvanes. 2016. "What Is the Case for Paid Maternity Leave?" Review of Economics and Statistics 98 (4): $655-670$.

Das, T., and S. Polachek. 2015. "Unanticipated effects of California's paid family leave program." Contemporary Economic Policy 33 (4): 619-635.

Dustmann, C., and U. Schönberg. 2012. "Expansions in Maternity Leave Coverage and Children's Long-Term Outcomes." American Economic Journal: Applied Economics 4 (3): 190-224.

Ejrnaes, M., and A. Kunze. 2013. "Work and wage dynamics around childbirth." The Scandinavian Journal of Economics 115 (3): 856-877.

Fitzenberger, B., K. Sommerfeld, and S. Steffes. 2013. "Causal effects on employment after first birth A dynamic treatment approach." Labour Economics $25: 49-62$.

Flinn, C. J., and J. J. Heckman. 1983. "Are unemployment and out of the labor force behaviorally distinct labor force states?" Journal of Labor Economics 1 (1): $28-42$. 
Fodor, E. 2005. "Women at work: The status of women in the labour markets of the Czech Republic, Hungary and Poland." JUNRISD Occasional paper 3/2005.

Francesconi, M. 2002. "A joint dynamic model of fertility and work of married women." Journal of Labor Economics 20 (2): 336-380.

Geyer, J., P. Haan, and K. Wrohlich. 2015. "The effects of family policy on maternal labor supply: Combining evidence froma structuralmodel and a quasiexperimental approach." Labour Economics 36:84-98.

Gönül, F. 1992. "New evidence on whether unemployment and out of the labor force are distinct states." The Journal of Human Resources 27 (2): 329-361.

Han, W.-J., C. Ruhm, and J. Waldfogel. 2009. "Parental leave policies and parents' employment and leave-taking." Journal of Policy Analysis and Management 28 (1): $29-54$.

Hashimoto, M., R. Percy, T. Schoellner, and B. A. Weinberg. 2004. "The long and short of it: Maternity leave coverage and women's labor market outcomes." IZA Discussion Paper, No. 120\%.

Jones, S. R. G., and W. C. Riddell. 1999. "The measurement of unemployment: An empirical approach." Econometrica 67 (1): 147-162.

Kantorova, V. 2004. "Education and entry into motherhood: The Czech Republic during state socialism and the transition period." Demographic Research Special Collections 3 (10): 245-274.

Krizkova, A., H. Haskova, L. Formankova, and H. Marikova. 2011. Pracovní dráhy žen v České republice [Women's careers in the Czech Republic]. Prague: Sociologické nakladatelství SLON.

Kucharova, V. 2006. Zamestnani a pece o male deti z perspektivy rodicu a zamest- 
navatelu [Employment and childcare from the perspective of parents and employers]. Prague: VUPSV v.v.i.

Lalive, R., A. Schlosser, A. Steinhauer, and J. Zweimüller. 2014. "Parental leave and mothers' careers: The relative importance of job protection and cash benefits." Review of Economic Studies 81 (1): 219-265.

Lalive, R., and J. Zweimüller. 2009. "How does parental leave affect fertility and return to work? Evidence from two natural experiments." The Quarterly Journal of Economics 124 (3): 1363-1402.

Miller, A. R. 2011. "The effects of motherhood timing on career path." Journal of Population Economics 24 (3): 1071-1100.

Moos, P. 2015. 11th International Review of Leave Policies and Research 2015. Institute of Education, University of London.

Mullerova, A. 2014. "Female labour supply in the Czech transition: Effects of the work-life conciliation policies." EconomiX Working Paper no. 2014-50.

. 2016. "Mind the employment gap: an impact evaluation of the Czech multi-speed parental benefit reform." EconomiX Working Paper no. 2016-30.

Naz, G. 2004. "The impact of cash-benefit reform on parents' labour force participation." Journal of Population Economics 17 (2): 369-383.

OECD. 2010. Use of childbirth-related leave by mothers and fathers. Paris: OECD Publishing.

- 2012. Closing the Gender Gap: Act Now. Paris: OECD Publishing.

Pencavel, J. 1998. "Assortative mating by schooling and the work behavior of wives and husbands." American Economic Review 88 (2): 326-329.

Sánchez-Mangas, R., and V. Sánchez-Marcos. 2008. "Balancing family and work: 
The effect of cash benefits for working mothers." Labour Economics 15 (6): $1127-1142$.

Schönberg, U., and J. Ludsteck. 2014. "Expansions in maternity leave coverage and mothers' labor market outcomes after childbirth." Journal of Labor Economics $32(3): 469-505$.

Schone, P. 2004. "Labour supply effects of a cash-for-care subsidy." Journal of Population Economics 17 (4): 703-727.

Sobotka, T. 2003. "Re-emerging diversity: Rapid fertility changes in Central and Eastern Europe after the collapse of the communist regimes." Population 58 (4): 451.

Spivey, C. 2005. "Time off at what price? The effects of career interruptions on earnings." Industrial and Labor Relations Review 59 (1): 119-140. 


\section{Appendix}

\section{Appendix A. Supplementary Tables and Figures}

Table A.1: Definition of the after-reform period by the age of the youngest child

\begin{tabular}{|c|c|c|c|c|c|c|c|}
\hline \multirow{2}{*}{$\begin{array}{c}\text { age of the } \\
\text { youngest child }\end{array}$} & \multicolumn{6}{|c|}{ year } & \\
\hline & \multicolumn{6}{|c|}{ Panel A: The 1995 reform } & \\
\hline & 1993-1995 Q3 & $1995 \mathrm{Q} 4$ & 1996 & 1997 & 1998 & 1999 & \\
\hline 2 & before & after & after & after & after & after & \\
\hline 3 & before & after* & after & after & after & after & \\
\hline 4 & before & . & after* & after & after & after & \\
\hline 5 & before & . & 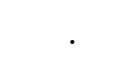 & after* & after & after & \\
\hline 6 & before & . & & . & after* & after & \\
\hline \multirow[t]{3}{*}{7} & before & 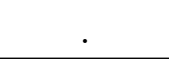 & & 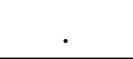 & 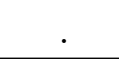 & after* & \\
\hline & \multicolumn{7}{|c|}{ Panel B: The 2008 reform } \\
\hline & $2004-2007$ & 2008 & 2009 & 2010 & 2011 & 2012 & 2013 \\
\hline 2 & before & after* & after & after & after & after & after \\
\hline 3 & before & . & after* & after & after & after & after \\
\hline 4 & before & . & . & after* & after & after & after \\
\hline 5 & before & . & . & . & after* & after & after \\
\hline 6 & before & . & 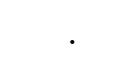 & . & . & after* & after \\
\hline 7 & before & . & & . & . & & after* \\
\hline
\end{tabular}

Note: The Table defines the after-reform period for each group of treated women by the age of their youngest child. The asterisk denotes the first cohorts affected by each reform-women whose youngest child was born in 1992 for the 1995 reform and in 2006 for the 2008 reform (for details on the institutional background of these reforms, see Section 2.1). The before and after periods are defined the same way for the corresponding control groups. 


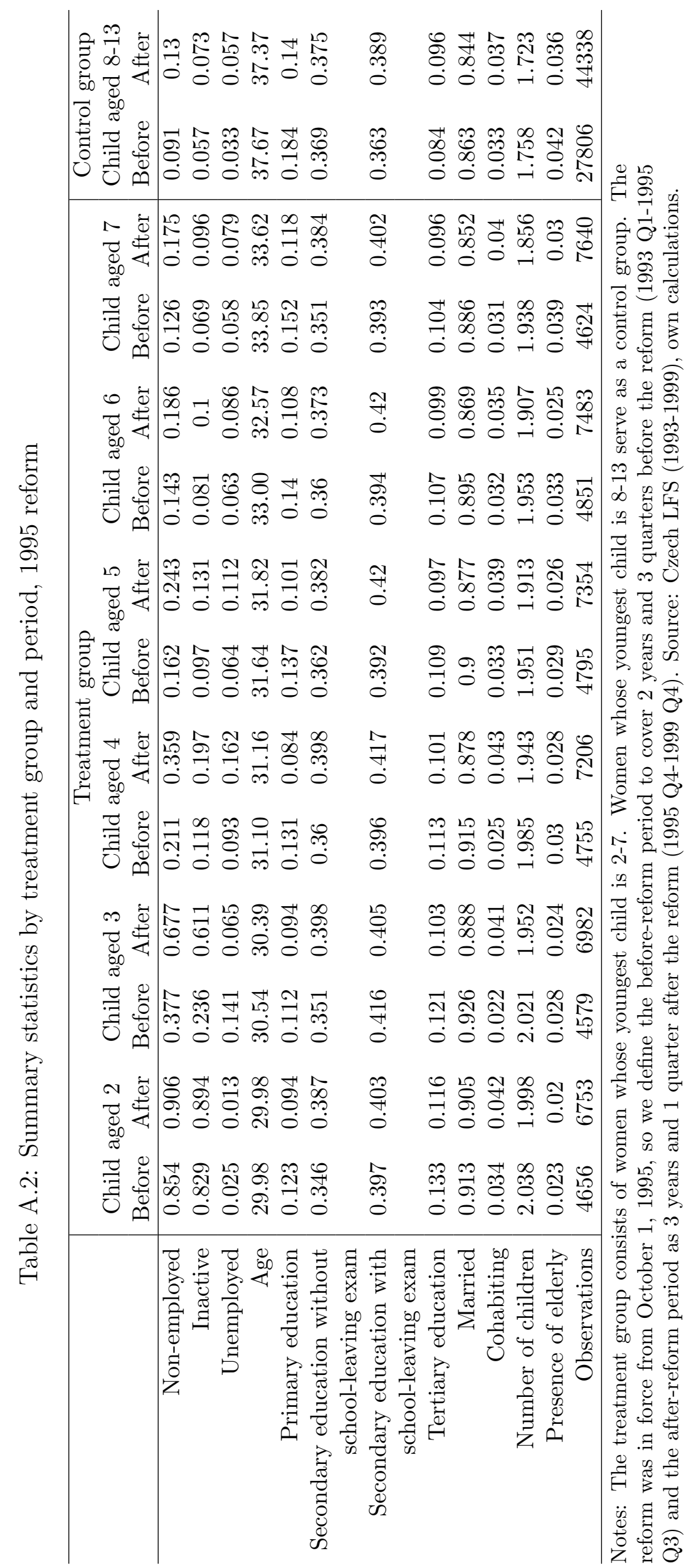




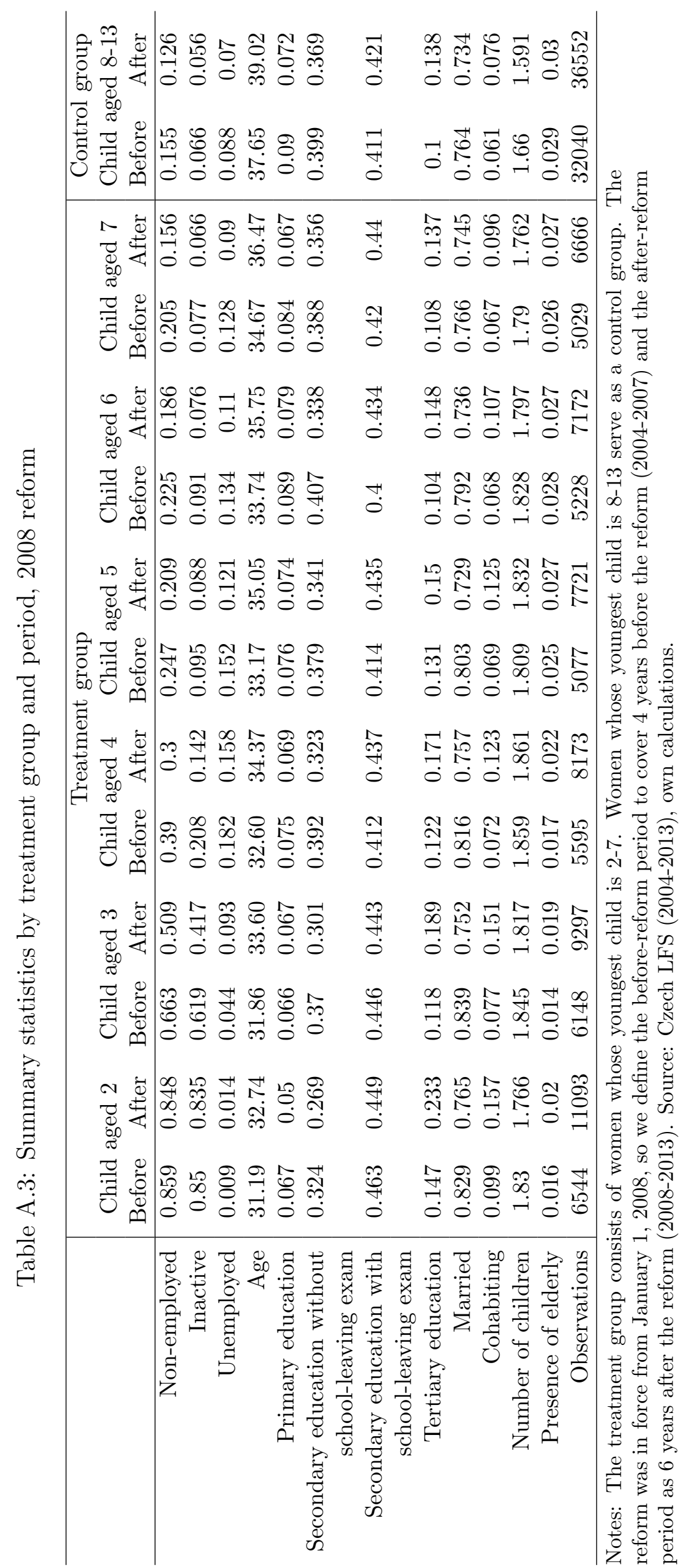


Table A.4: Robustness check: Alternative control groups

\begin{tabular}{|c|c|c|c|c|c|}
\hline \multirow{3}{*}{$\begin{array}{l}\text { Treatment group: } \\
\text { women whose } \\
\text { youngest child is: }\end{array}$} & & \multicolumn{4}{|c|}{ Impact on non-employment } \\
\hline & & \multicolumn{2}{|c|}{1995 reform } & \multicolumn{2}{|c|}{2008 reform } \\
\hline & & baseline & robust & baseline & robust \\
\hline \multirow{4}{*}{ aged 2} & Treat*After & 0.011 & $0.033^{* * *}$ & $0.029 * * *$ & $0.019 * * *$ \\
\hline & & $(0.007)$ & $(0.007)$ & $(0.006)$ & $(0.005)$ \\
\hline & R-squared & 0.444 & 0.344 & 0.456 & 0.404 \\
\hline & Observations & 83549 & 145265 & 86228 & 150096 \\
\hline \multirow{4}{*}{ aged 3} & Treat*After & $0.256^{* * *}$ & $0.279^{* * *}$ & $-0.147^{* * *}$ & $-0.157^{* * *}$ \\
\hline & & $(0.016)$ & $(0.018)$ & $(0.013)$ & $(0.014)$ \\
\hline & R-squared & 0.232 & 0.184 & 0.243 & 0.214 \\
\hline & Observations & 83701 & 145417 & 75829 & 132674 \\
\hline \multirow{4}{*}{ aged 4} & Treat*After & $0.115^{* * *}$ & $0.139^{* * *}$ & $-0.080^{* * *}$ & $-0.095 * * *$ \\
\hline & & $(0.014)$ & $(0.016)$ & $(0.007)$ & $(0.009)$ \\
\hline & R-squared & 0.104 & 0.095 & 0.14 & 0.121 \\
\hline & Observations & 80879 & 139979 & 66997 & 117087 \\
\hline \multirow{4}{*}{ aged 5} & Treat*After & $0.049^{* * *}$ & $0.081^{* * *}$ & $-0.010^{*}$ & $-0.027 * * *$ \\
\hline & & $(0.007)$ & $(0.008)$ & $(0.006)$ & $(0.006)$ \\
\hline & R-squared & 0.079 & 0.079 & 0.117 & 0.1 \\
\hline & Observations & 68347 & 117128 & 58713 & 103110 \\
\hline \multirow{4}{*}{ aged 6} & Treat*After & $0.018^{* *}$ & $0.047^{* * *}$ & $-0.019 * * *$ & $-0.031^{* * *}$ \\
\hline & & $(0.007)$ & $(0.006)$ & $(0.006)$ & $(0.007)$ \\
\hline & R-squared & 0.072 & 0.077 & 0.118 & 0.097 \\
\hline & Observations & 56513 & 96132 & 51286 & 90109 \\
\hline \multirow{4}{*}{ aged 7} & Treat*After & 0.011 & $0.049 * * *$ & $-0.040^{* * *}$ & $-0.043^{* * *}$ \\
\hline & & $(0.007)$ & $(0.007)$ & $(0.006)$ & $(0.006)$ \\
\hline & R-squared & 0.069 & 0.075 & 0.115 & 0.094 \\
\hline & Observations & 44293 & 75022 & 43896 & 77444 \\
\hline
\end{tabular}

Note: The treatment groups consist of prime-aged women (aged 25-55) whose youngest child is 2-7. In the baseline specification, the control group consists of prime-aged women whose youngest child is 8-13. In the robust specification, the control group consists of prime-aged women whose youngest child is 13-23 for the 1995 reform and 18-25 for the 2008 reform. For each treatment group, a separate regression is estimated by the age of the youngest child, but the control group is fixed in all regressions. All regressions include dummies for the treatment group and after period, quarter-year dummies, quarter-year dummies interacted with level of education, and other control variables. The beginning of the after-period for the treatment group is set to the year when a mother of a child of a given age becomes affected by the reform. Standard errors (in parentheses) are clustered at the group-year level $\left(* \mathrm{p}<0.10,{ }^{* *} \mathrm{p}<0.05,{ }^{* * *} \mathrm{p}<0.01\right)$. Source: Czech LFS (1993-1999 and 2004-2013), own calculations. 
Table A.5: Robustness check: Changes in parental allowance in 2007 and 2011

\begin{tabular}{|c|c|c|c|c|}
\hline \multirow{2}{*}{$\begin{array}{l}\text { Treatment group: } \\
\text { women whose } \\
\text { youngest child is: }\end{array}$} & & \multicolumn{3}{|c|}{$\begin{array}{c}\text { Impact on non-employment } \\
2008 \text { reform }\end{array}$} \\
\hline & & baseline & robust 2007 & robust 2011 \\
\hline \multirow{4}{*}{ aged 2} & Treat*After & $0.029^{* * *}$ & $0.036^{* * *}$ & $0.037^{* * *}$ \\
\hline & & $(0.006)$ & $(0.006)$ & $(0.006)$ \\
\hline & R-squared & 0.456 & 0.418 & 0.418 \\
\hline & Observations & 86228 & 75797 & 81045 \\
\hline \multirow{4}{*}{ aged 3} & Treat*After & $-0.147 * * *$ & $-0.150 * * *$ & $-0.136^{* * *}$ \\
\hline & & $(0.013)$ & $(0.007)$ & $(0.017)$ \\
\hline & R-squared & 0.243 & 0.221 & 0.243 \\
\hline & Observations & 75829 & 66176 & 73037 \\
\hline \multirow{4}{*}{ aged 4} & Treat*After & $-0.080^{* * *}$ & $-0.092^{* * *}$ & $-0.078^{* * *}$ \\
\hline & & $(0.007)$ & $(0.007)$ & $(0.007)$ \\
\hline & R-squared & 0.14 & 0.139 & 0.14 \\
\hline & Observations & 66997 & 58015 & 65945 \\
\hline \multirow{4}{*}{ aged 5} & Treat*After & $-0.010^{*}$ & $-0.017^{* * *}$ & $-0.010^{*}$ \\
\hline & & $(0.006)$ & $(0.005)$ & $(0.006)$ \\
\hline & R-squared & 0.117 & 0.116 & 0.117 \\
\hline & Observations & 58713 & 50785 & 58713 \\
\hline \multirow{4}{*}{ aged 6} & Treat*After & $-0.019 * * *$ & & $-0.019 * * *$ \\
\hline & & $(0.006)$ & & $(0.006)$ \\
\hline & R-squared & 0.118 & & 0.118 \\
\hline & Observations & 51286 & & 51286 \\
\hline \multirow{4}{*}{ aged 7} & Treat*After & $-0.040 * * *$ & & $-0.040^{* * *}$ \\
\hline & & $(0.006)$ & & $(0.006)$ \\
\hline & R-squared & 0.115 & & 0.115 \\
\hline & Observations & 43896 & & 43896 \\
\hline
\end{tabular}

Note: In the baseline specification, the treatment groups consist of prime-aged women (aged 25-55) whose youngest child is 2-7 and the control group consists of prime-aged women whose youngest child is 8-13. In the robust 2007 specification, we drop from the sample women with a child 0-3 in 2007. In the robust 2011 specification, we drop from the sample women with a child under 2 at the beginning of 2011. For each treatment group, a separate regression is estimated by the age of the youngest child, but the control group is fixed in all regressions. All regressions include dummies for the treatment group and after period, quarter-year dummies, quarter-year dummies interacted with level of education, and other control variables. The beginning of the after-period for the treatment group is set to the year when a mother of a child of a given age becomes affected by the reform. Standard errors (in parentheses) are clustered at the group-year level $\left(^{*} \mathrm{p}<0.10\right.$, $\left.{ }^{* *} \mathrm{p}<0.05,{ }^{* * *} \mathrm{p}<0.01\right)$. Source: Czech LFS (2004-2013), own calculations. 
Figure A.1: Fertility rates, 1993-2012

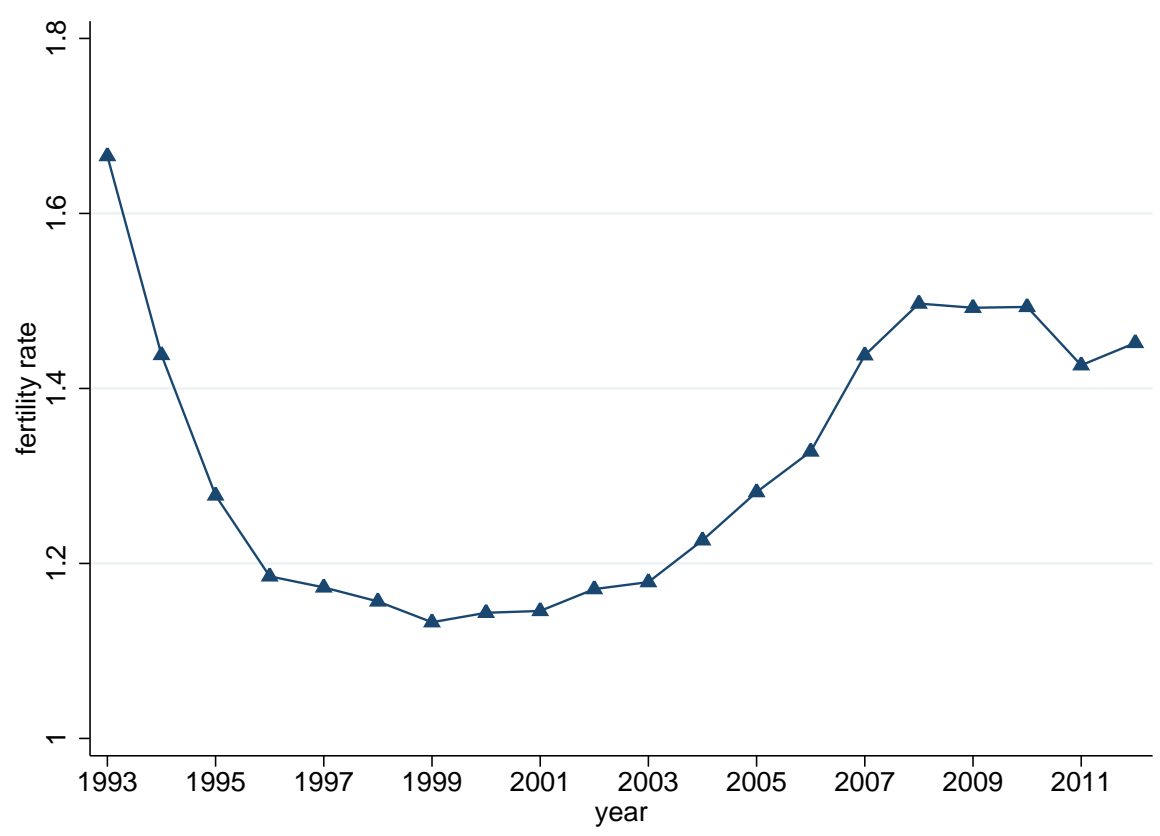

Note: The figure depicts fertility rates in the Czech Republic in 1993-2012. The fertility rate represents the number of children that would be born to a woman if she were to live to the end of her childbearing years and bear children in accordance with current age-specific fertility rates. Source: Czech Statistical Office. 


\section{Appendix B. Identification Assumptions}

Our empirical strategy assumes that trends in labor market status of the treatment groups (of women whose youngest child is 2-7) and that of the control group (of women whose youngest child is 8-13) would have been the same in the absence of treatment. To provide some evidence regarding the validity of this assumption, we plot the evolution of the non-employment and unemployment-to-population rates of all the treatment groups and the control group over the two studied periods in Appendix Figures A.2-A.5. The after period for each group of treated women by the age of their youngest child is denoted by a thick line. ${ }^{57}$ In order to focus on aggregate trends, all time series presented in this section were seasonally adjusted using standard MA(4) smoothing.

The evolution of non-employment rate over the first period, covering the 1995 reform, is presented in Figure A.2. The non-employment rate of all groups of treated women followed quite closely the control group in the pre-treatment period. Women with children aged 3 experienced a somewhat greater increase in their non-employment rate in the early pre-treatment period (compared to the control group), but it stabilized in the fourth quarter of 1994 and did not change much in the rest of the pre-reform period.

Figure A.3 in the Appendix shows the evolution of the unemployment-to-population rate. While the control group's unemployment was relatively stable over the whole pre-treatment period, women with children aged 2 experienced a gradual decrease in their unemployment probability, and unemployment probability of women with slightly older children (3 and 4) increased somewhat in 1993 and 1994. The unemploymentto-population rate for mothers with children aged 5, 6, and 7 follows the overall evolution of the control group reasonably well. While the validity of the common

\footnotetext{
${ }^{57}$ The after-reform period for each group of treated women starts in the quarter in which the youngest child of women who were eligible for the after-reform parental allowance reached the age by which that treatment group is defined (for details on after period definition see Section 3.1).
} 
trend assumption for unemployment might be thus questioned for some groups of treated women, the divergences in trends are very small compared to the size of the impact of the reform that we find.

The common trend assumption for the 2008 reform is investigated in Appendix Figures A.4 and A.5. The non-employment rates of women with children aged 2-7 are quite stable, sometimes with a mild decrease, in the pre-treatment period, but are quite similar to the control group of women with children aged 8-13 (see Figure A.4). The share of the unemployed women with children aged 2 is very low (below $2 \%$ ) and relatively stable over the whole pre-reform period (Figure A.5). Women with children aged 3, 4, and 6 experienced some increase in unemployment probability in the second half of 2005 or in 2006 and a subsequent unemployment decline, which was consistent with the evolution of the control group. Therefore, the common trend assumption seems to be quite reasonable for both the non-employment and unemployment-to-population rates around the 2008 reform.

The empirical strategy further requires that there were no significant composition changes in the treatment and control groups. This assumption could be violated if fertility decisions of Czech couples were significantly influenced by reforms of the parental allowance, and the fertility changes then affected the composition of the treatment and control groups. The trends in fertility in the 1990s and early 2000s are described in Figure A.1 and seem unrelated to the reforms of parental allowance. While fertility evolved rather dynamically over the two periods we study, the changes are in the opposite direction than the potential impact we would expect the reforms to have on fertility and are driven, primarily, by external factors. ${ }^{58}$

Finally, one might argue that the substantial impact of the reforms on labor force participation of women with young children could have caused an aggregate

\footnotetext{
${ }^{58}$ The steep decline in fertility rates in the 1990s started long before the 1995 reform and was part of a general trend that decreased fertility in all post-communist countries (Sobotka 2003). Fertility changes in the 2000s also took place before the 2008 reform and were mainly a consequence of a generation of baby boomers from the 1970s entering childbearing age.
} 
labor market shock to the labor supply of young women. To the extent to which women with older children (our control group) are substitutes for women with young children (affected by the reforms), this may violate our identification assumptions. All our treatment groups together constitute only $36 \%$ of women aged 25-40. Even if this share could generate a market-wide shock, this argument should not undermine our results: First, the potential (opposite) impact of the reforms on the control group presupposes the existence of the effect on the treatment groups that we find. Second, such impact would only bias our results downwards, suggesting that our already sizable estimates represent a lower bound of the true effects of the reforms. 
Figure A.2: Non-employment rate of women by the age of their youngest child, 1993-1999.

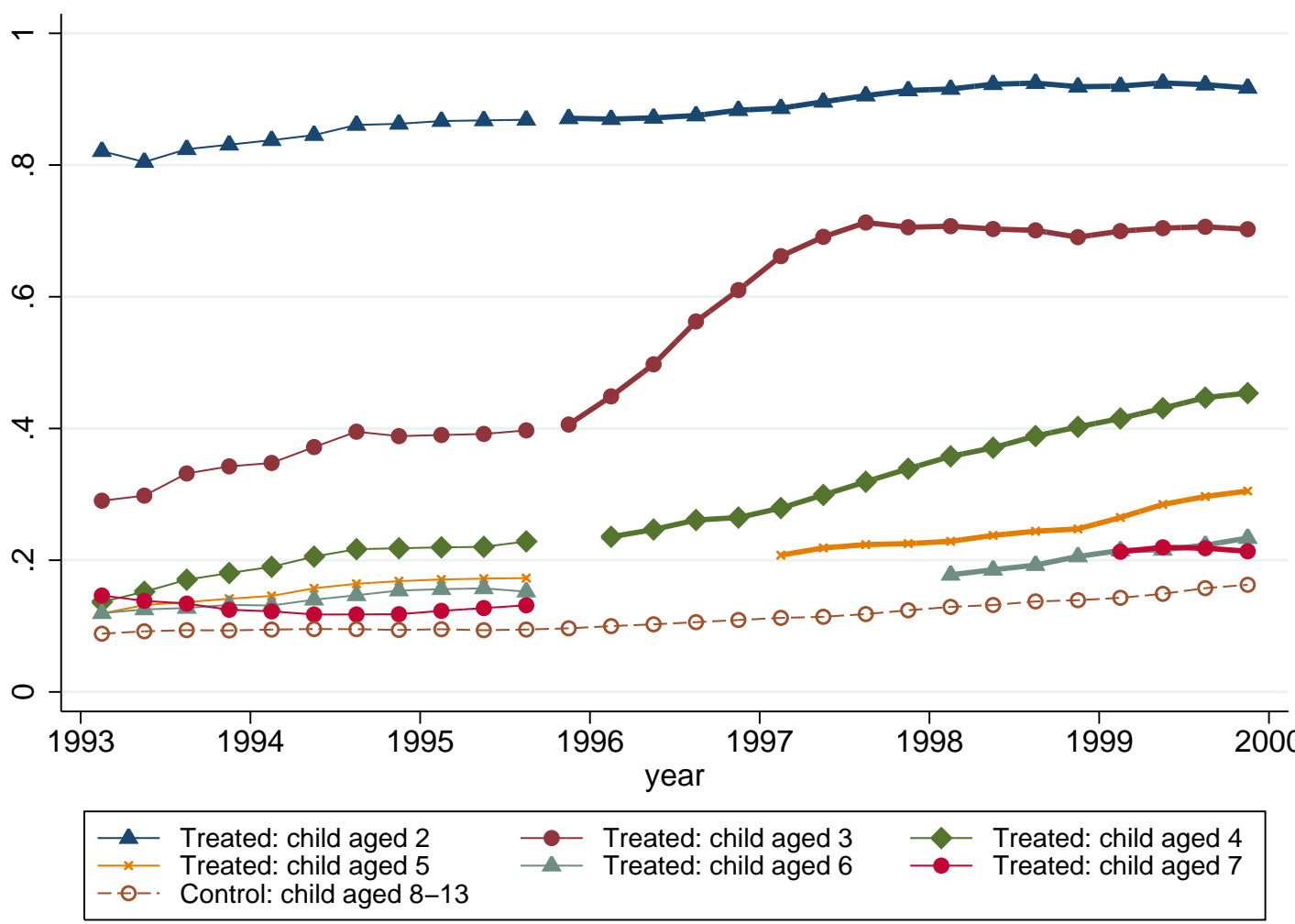

Note: The figure depicts the non-employment rate (share of inactive and unemployment in the population) for women in the treatment and control groups by the age of their youngest child. The after reform period is denoted by a thick line for each group of treated women. The time series were seasonally adjusted using MA(4) smoothing. Source: Czech LFS data (1993-1999). 
Figure A.3: Unemployment-to-population rate of women by the age of their youngest child, 1993-1999.

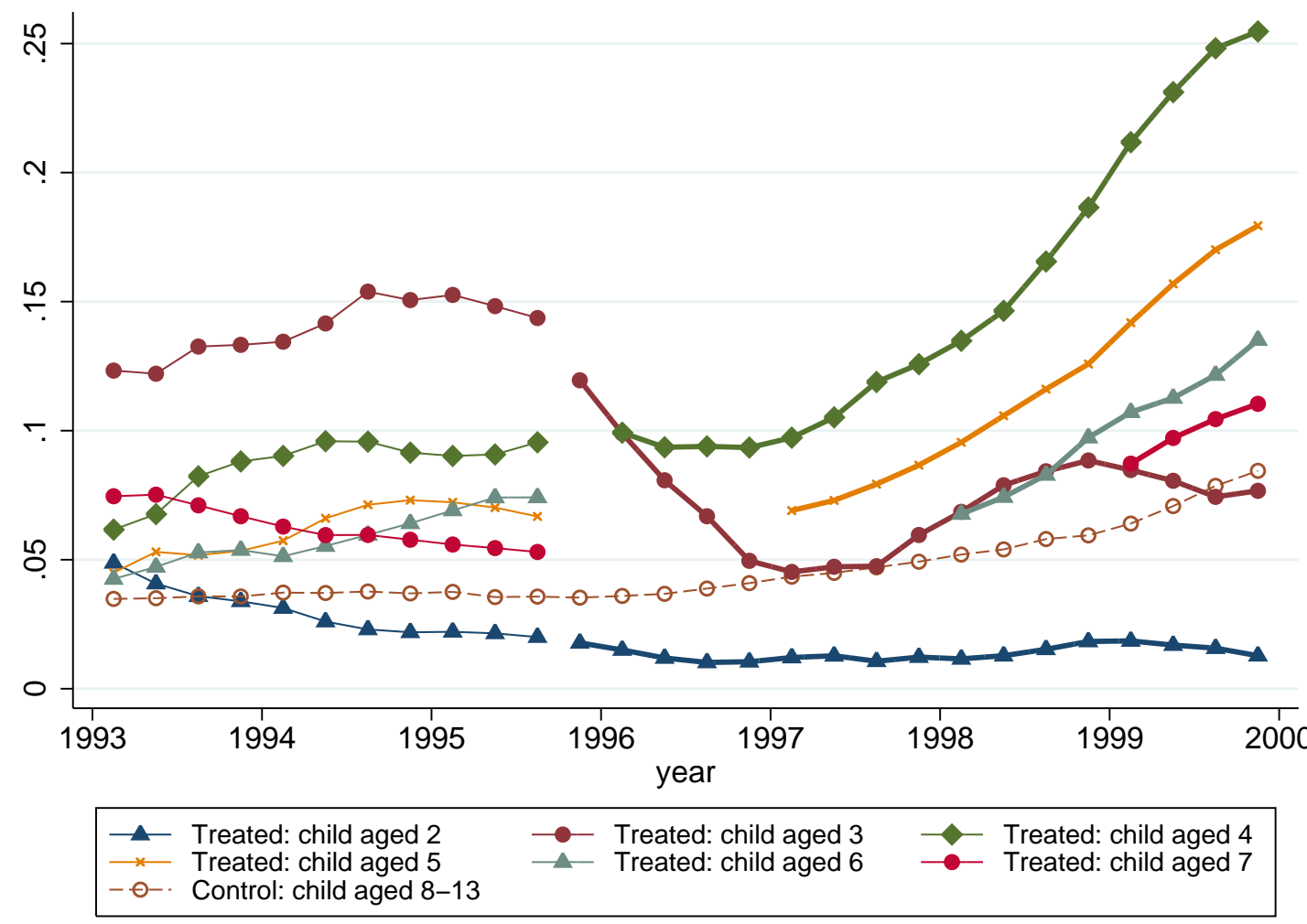

Note: The figure depicts the unemployment-to-population rate (share of unemployment in the population) for women in the treatment and control groups by the age of their youngest child. The after reform period is denoted by a thick line for each group of treated women. The time series were seasonally adjusted using MA(4) smoothing. Source: Czech LFS data (1993-1999). 
Figure A.4: Non-employment rate of women by the age of their youngest child, 2004-2013.

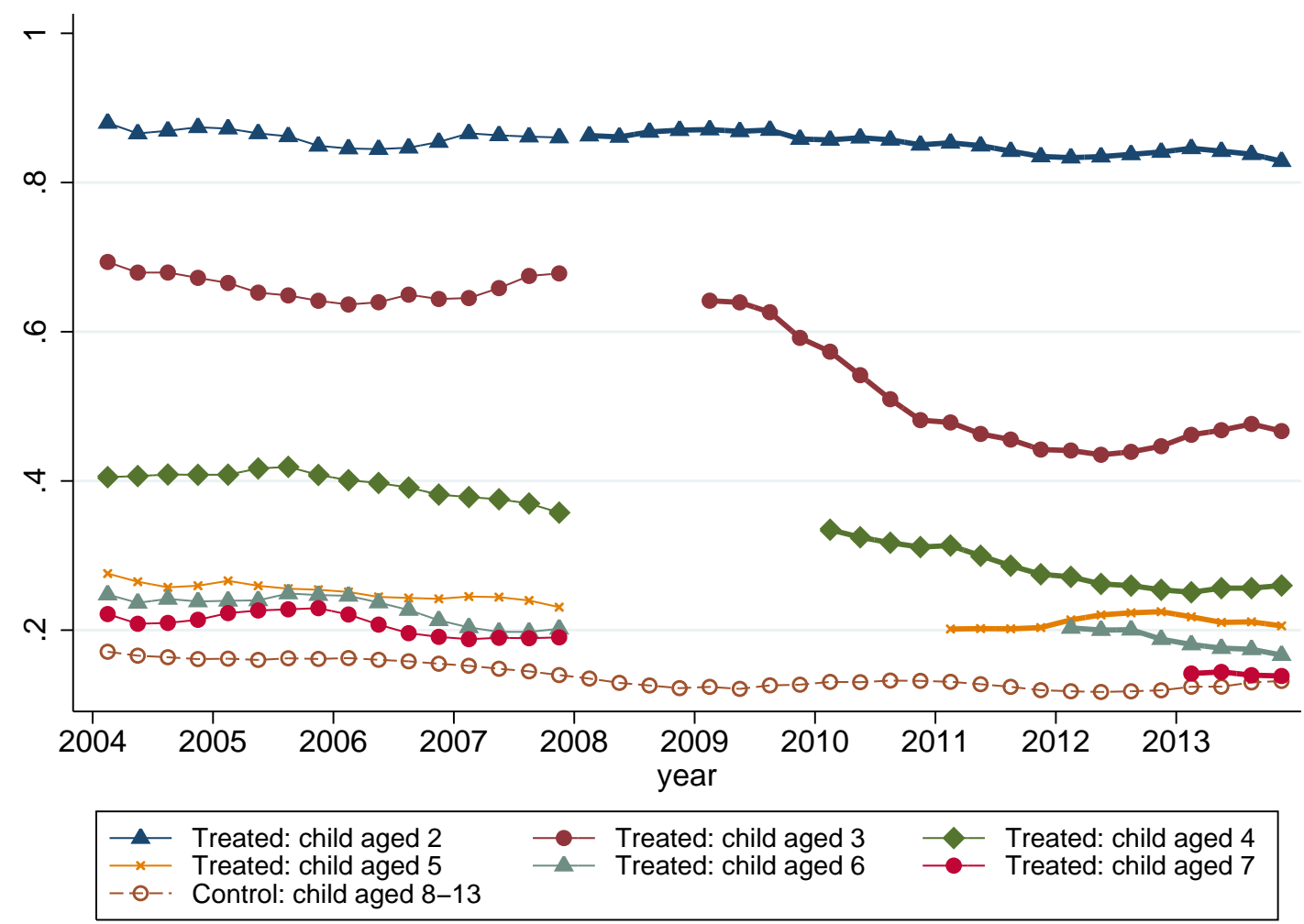

Note: The figure depicts the non-employment rate (share of inactive and unemployed in the population) for women in the treatment and control groups by the age of their youngest child. The after reform period is denoted by a thick line for each group of treated women. The time series were seasonally adjusted using MA(4) smoothing. Source: Czech LFS data (2004-2013). 
Figure A.5: Unemployment-to-population rate of women by the age of their youngest child, 2004-2013.

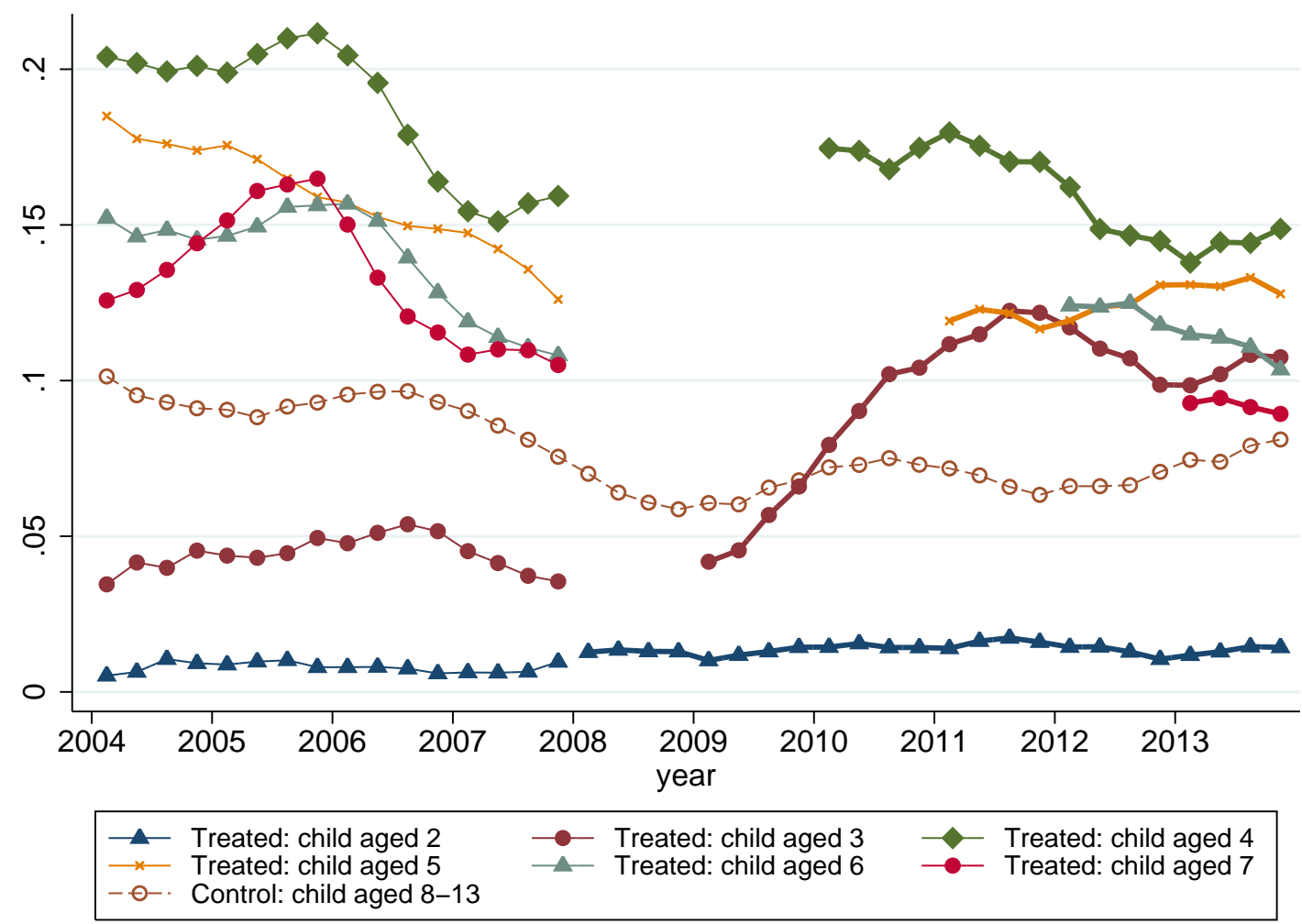

Note: The figure depicts the unemployment-to-population rate (share of unemployment in the population) for women in the treatment and control groups by the age of their youngest child. The after reform period is denoted by a thick line for each group of treated women. The time series were seasonally adjusted using MA(4) smoothing. Source: Czech LFS data (2004-2013). 


\begin{abstract}
Abstrakt
Česká republika je zemí s velmi vysokou mírou zaměstnanosti žen, ale také jednou z nejdelších placených rodičovských dovolených, po které často následuje období nezaměstnanosti. V této studii používáme metodu rozdílu-v-rozdílech pro odhad dopadu dvou reforem délky pobírání rodičovského příspěvku na ekonomický status žen 2-7 let po porodu jejich nejmladšího dítěte. Zatímco reforma z roku 1995 prodloužila délku pobírání rodičovského příspěvku z 3 na 4 roky, reforma z roku 2008 umožnila některým rodičům zkrátit si pobírání příspěvku na 2 nebo 3 roky s ekvivalentní celkovou peněžní částkou. Ukazujeme, že v důsledku reformy z roku 1995 si 36\% matek prodloužilo rodičovskou dovolenou na dobu delší než tři roky, po kterou mají právo na návrat do původního zaměstnání. Reforma z roku 2008 částečně zvrátila tento efekt. Obě reformy měly silný vliv na nezaměstnanost a neaktivitu matek po rodičovské dovolené.
\end{abstract}




\section{Working Paper Series}

ISSN 1211-3298

Registration No. (Ministry of Culture): E 19443

Individual researchers, as well as the on-line and printed versions of the CERGE-EI Working Papers (including their dissemination) were supported from institutional support RVO 67985998 from Economics Institute of the ASCR, v. v. i.

Specific research support and/or other grants the researchers/publications benefited from are acknowledged at the beginning of the Paper.

(c) Alena Bičáková, Klára Kalíšková, 2016

All rights reserved. No part of this publication may be reproduced, stored in a retrieval system or transmitted in any form or by any means, electronic, mechanical or photocopying, recording, or otherwise without the prior permission of the publisher.

Published by

Charles University in Prague, Center for Economic Research and Graduate Education (CERGE) and

Economics Institute of the CAS, v. v. i. (EI)

CERGE-El, Politických vězňů 7, 11121 Prague 1, tel.: +420 224005 153, Czech Republic.

Printed by CERGE-EI, Prague

Subscription: CERGE-EI homepage: http://www.cerge-ei.cz

Phone: + 420224005153

Email: office@cerge-ei.cz

Web: http://www.cerge-ei.cz

Editor: Jan Zápal

The paper is available online at http://www.cerge-ei.cz/publications/working_papers/.

ISBN 978-80-7343-375-8 (Univerzita Karlova v Praze, Centrum pro ekonomický výzkum a doktorské studium)

ISBN 978-80-7344-391-7 (Národohospodářský ústav AV ČR, v. v. i.) 
CERGE-EI

P.O.BOX 882

Politických vězňů 7

11121 Praha 1

Czech Republic http://www.cerge-ei.cz 